\title{
Molecular Electrochemical Reductive Splitting of Dinitrogen with a Molybdenum Complex
}

\author{
Lydia Merakeb $^{\mathrm{a}, \sharp}$, Soukaina Bennaamane ${ }^{\mathrm{b}, \star}$, Eric Clot, ${ }^{\mathrm{c}}$ Nicolas Mézailles $^{\mathrm{b}^{*}}$ and Marc Robert ${ }^{\mathrm{a}, \mathrm{d}^{*}}$

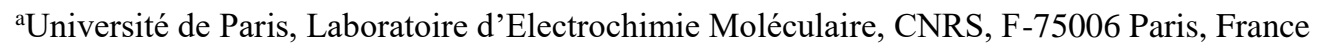

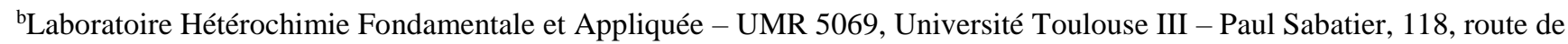 \\ Narbonne, Bât. 2R1, 31062, Toulouse, France \\ 'ICGM Univ Montpellier, CNRS, ENSCM, Montpellier, France \\ ${ }^{\mathrm{d} I n s t i t u t ~ U n i v e r s i t a i r e ~ d e ~ F r a n c e ~(I U F), ~ F-75005, ~ P a r i s, ~ F r a n c e ~}$
}

KEYWORDS. Dinitrogen reductive splitting, electrochemical reduction of $\mathrm{N}_{2}$, molybdenum complex, nitride Mo complex

\begin{abstract}
Nitrogen reduction in mild conditions (i.e. room temperature and atmospheric pressure) and using a non-fossil source of hydrogen remains a high chemistry challenge. Molecular metal complexes, notably Mo based, have recently shown to be active for such nitrogen fixation. In this work, we report about the electrochemical $\mathrm{N}_{2}$ splitting with $\mathrm{Mo}^{\mathrm{III}}$ triphosphino complex ((PPP) $\left.\mathrm{MoI}_{3}\right)$, at room temperature and a moderately negative potential. A $\mathrm{Mo}^{\mathrm{IV}}$ nitride species was generated, which was confirmed by electrochemistry and NMR studies. The reaction goes through the bi-electronic reduction of the starting Mo species, coordination of an $\mathrm{N}_{2}$ molecule, and further splitting to a $\mathrm{Mo}^{\mathrm{IV}}$ nitride complex. Preliminary DFT investigation supports the intermediacy of a bridging $\mathrm{Mo}^{\mathrm{I}} \mathrm{N}_{2} \mathrm{Mo}^{\mathrm{I}}$ dinitrogen dimer evolving to the Mo nitride via a low energy transition state. This example joins a short list of molecular electrochemical complexes for $\mathrm{N}_{2}$ reductive cleavage. It opens a door to molecular electrochemical PCET conversion studies of $\mathrm{N}_{2}$ to $\mathrm{NH}_{3}$.
\end{abstract}

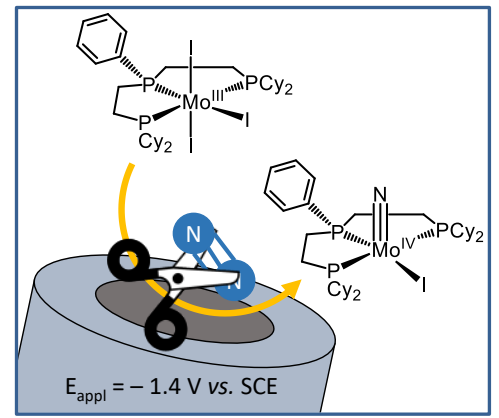

\section{INTRODUCTION}

Nitrogen is one of the essential elements for life. ${ }^{1}$ Although abundant, it is nonetheless a limiting nutrient in agriculture, and crops growth is dependent on its availability. ${ }^{2}$ It is not only essential to the global economy as a fertilizer but also as the feedstock for industrial production of all $\mathrm{N}$ containing derivatives. Moreover, it has been identified as an alternative fuel as well as an energy storage molecule. ${ }^{3,4}$ Today, $c a .200$ million tons of $\mathrm{NH}_{3}$ are produced yearly, exclusively by the Haber-Bosch (HB) process (equation (1)).

$$
\mathrm{N}_{2}+3 \mathrm{H}_{2} \rightleftarrows 2 \mathrm{NH}_{3} \quad \Delta_{\mathrm{r}} G^{0}=32.9 \mathrm{~kJ} \mathrm{~mol}^{-1}
$$

Although thermodynamically favorable, the reaction is carried out at high temperature $\left(300-500{ }^{\circ} \mathrm{C}\right)$ and high pressure $(200$ 300 bars) conditions over heterogeneous $\mathrm{Fe}$ containing catalysts, using $c a$. $1-2 \%$ of the global energy production. It generates half a Gigaton of $\mathrm{CO}_{2} /$ year $\left(\mathrm{ca} .1 / 2\right.$ of the $\mathrm{CO}_{2}$ generated is due to $\mathrm{H}_{2}$ production by $\mathrm{CH}_{4}$ reforming), a giant carbon footprint.

Nature, by the means of microorganisms, transforms $\mathrm{N}_{2}$ into $\mathrm{NH}_{3}$ under ambient conditions, via multiple proton/electron transfers. ${ }^{5}$ Nitrogenase enzymes, responsible for this " $\mathrm{N}_{2}$ fixation" reaction (equation (2)), contain an organometallic active site, a cluster " $\mathrm{MoFe}_{7} \mathrm{~S}_{9} \mathrm{C}$-homocitrate" which can be viewed as a homogeneous catalyst. The fact that this catalyst involves a coordination/activation of $\mathrm{N}_{2}$ at one/several metal centers has spurred "organometallic chemists" to search for homogeneous catalysts able to achieve the $\mathrm{N}_{2}$-to- $-\mathrm{NH}_{3}$ reaction efficiently.

$\mathrm{N}_{2}+8 \mathrm{H}^{+}+8 \mathrm{e}^{-}+16 \mathrm{ATP} \rightleftarrows 2 \mathrm{NH}_{3}+\mathrm{H}_{2}+16 \mathrm{ADP}+16 \mathrm{P}_{\mathrm{i}}$ (2)

Transition metal complexes based on $\mathrm{Mo}^{6-12}$ and $\mathrm{Fe}{ }^{13-16}$, mainly, but also rhenium ${ }^{17-19}$, vanadium ${ }^{20}$, chromium ${ }^{21-23}$, cobalt ${ }^{24,25}$ and titanium ${ }^{26}$ have been investigated. However, a major hurdle toward such chemistry lies in the kinetically favorable proton reduction into $\mathrm{H}_{2}$. Thus, despite several decades of active research, only a handful of catalysts are known for this reaction. Regarding electrochemical nitrogen splitting with molecular complexes, ${ }^{27-29}$ an initial example was identified by Picket and Talarmin with a W complex ${ }^{30}$ and in recent years, work has been performed on $\mathrm{Ti}^{31}$ and $\mathrm{Al}^{32}$ based complexes as well. The first and only so far example of electrochemically driven $\mathrm{N}_{2}$-to- $\mathrm{NH}_{3}$ catalytic conversion with a well-defined molecular species was reported in 2016. $\mathrm{P}_{3}{ }^{\mathrm{B}} \mathrm{Fe}\left(\mathrm{N}_{2}\right)^{-}\left(\mathrm{P}_{3}{ }^{\mathrm{B}}=\operatorname{tris}(\mathrm{o}-\right.$ diisopropylphosphinophenyl)borane) converts $\mathrm{N}_{2}$ to $\mathrm{NH}_{3}$ in $\mathrm{Et}_{2} \mathrm{O}$ containing $0.1 \mathrm{M} \mathrm{Na}\left[\mathrm{BAr}_{4}^{\mathrm{F}}\right.$ ] as a supporting electrolyte $\left(\mathrm{BAr}_{4}{ }_{4}=\right.$ tetrakis (3,5-bis(trifluoromethyl)phenyl)borate) at -45 ${ }^{\circ} \mathrm{C}$ (Scheme 1a). With 50 eq. of $\mathrm{H}\left[\mathrm{Bar}^{\mathrm{F}}{ }_{4}\right]$ as a proton source and upon applying a potential of $-2.3 \mathrm{~V} \mathrm{vs}$. $\mathrm{Fc} / \mathrm{Fc}^{+}, 2.2$ eq. of ammonia were produced with $25 \%$ Faradaic efficiency over 16.5 h. ${ }^{33}$ 
Scheme 1. Previous examples of molecular electrochemical reduction of $\mathrm{N}_{2}$ to $\mathrm{NH}_{3}(\mathrm{a}$ ), hydrazine (b) or nitride complexes (ce).

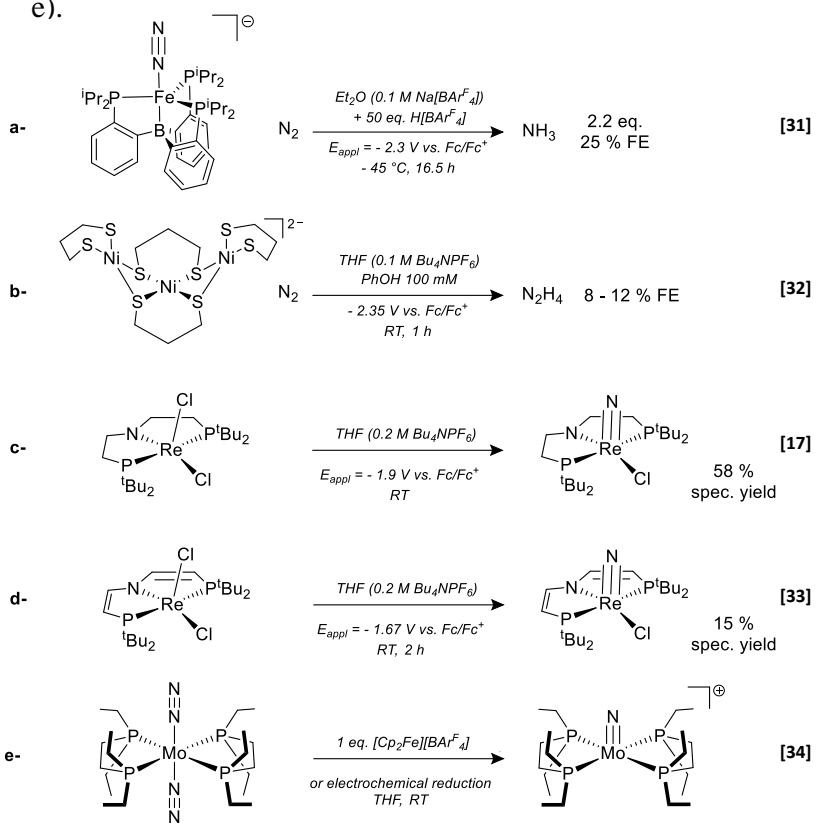

More recently, electrochemical reduction of $\mathrm{N}_{2}$ to hydrazine was shown on a tri-nickel based molecular catalyst. In THF $(0.1$ $\left.\mathrm{M} \mathrm{Bu}_{4} \mathrm{NPF}_{6}\right), \mathrm{N}_{2}$ was converted into $\mathrm{N}_{2} \mathrm{H}_{4}$ at $-2.35 \mathrm{~V} v s$. Fc/ $\mathrm{Fc}^{+}$ with 8 to $12 \%$ Faradaic efficiency, in the presence of $0.1 \mathrm{M}$ phenol as a proton source (Scheme 1b). ${ }^{34}$

Electrochemical $\mathrm{N}_{2}$ activation through splitting of the triple bond into metal nitrides has been recently the focus of several studies. Schneider, Siewert and coworkers ${ }^{18}$ have used a $\operatorname{Re}^{\mathrm{III}}$ complex for electrochemical conversion into $\mathrm{Re}^{\mathrm{V}}$-nitride in 58 $\%$ yield at $E=-1.9 \mathrm{~V}$ vs. $\mathrm{Fc} / \mathrm{Fc}^{+}$in presence of dinitrogen (Scheme 1c). Using a rhenium complex with a similar but more conjugated pincer ligand led to $\mathrm{N}_{2}$ splitting at a less cathodic potential, however at the expense of a lower yield (Scheme 1d). ${ }^{35}$ Remarkably, Masuda et al. showed that splitting of dinitrogen into terminal nitrides is also possible by chemical and electrochemical oxidation of a $\mathrm{N}_{2}$-bound $\mathrm{Mo}^{0}$ complex (Scheme 1e). ${ }^{36}$ Still regarding molybdenum, we have shown that the splitting of $\mathrm{N}_{2}$ could be achieved through the two electron reduction of a (PPP) $\mathrm{MoCl}_{3}$ complex (Scheme 2a) in the presence of NaI, and subsequently studied the functionalization of the nitride complex by silanes and boranes. ${ }^{10}$ These experimental studies, coupled to DFT calculations demonstrated the facile

Scheme 2. Molybdenum complex for $\mathrm{N}_{2}$ splitting in chemical (a) and electrochemical (b) reductive conditions.
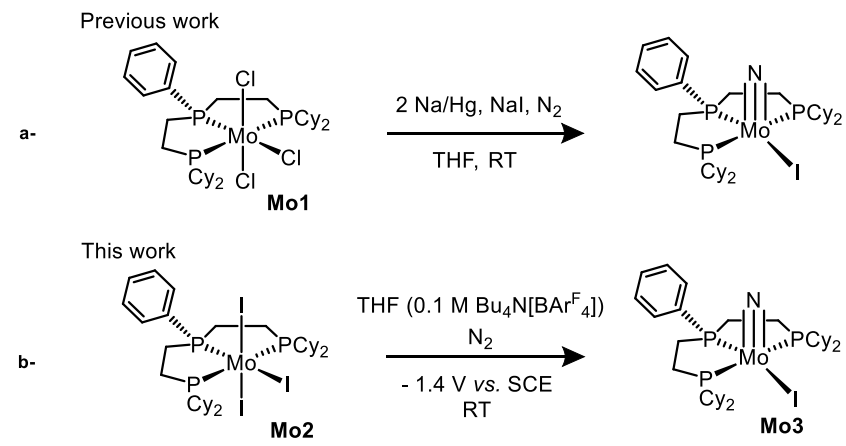

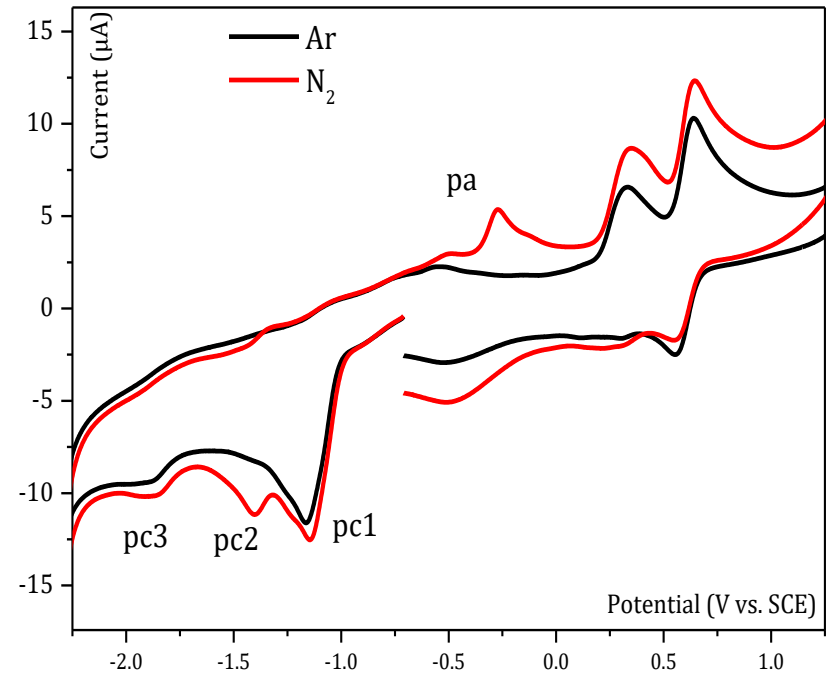

Figure 1. CVs of $\mathrm{Mo2}(0.58 \mathrm{mM})$ in THF $+0.1 \mathrm{M} \mathrm{Bu} 4 \mathrm{~N}\left[\mathrm{Bar}_{4}{ }^{\mathrm{F}}\right]$ at a glassy carbon electrode, under $\mathrm{Ar}$ (black) and $\mathrm{N}_{2}$ (red), at $v=100$ $\mathrm{mV} / \mathrm{s}$ and room temperature (RT).

transformation of the nitride to imido (boryl and silyl) and to amido derivatives, which are related to the key intermediates toward complete reduction to ammonia. ${ }^{37}$ In this work, we achieved the electrochemical splitting of dinitrogen with a Mo ${ }^{\mathrm{III}}$ tris-phosphino complex (PPP) $\mathrm{MoI}_{3}$ (Mo2, Scheme 2b) that leads to the formation of the corresponding Mo-nitride complex, at room temperature and moderate potential.

\section{RESULTS AND DISCUSSION}

The cyclic voltammetry of Mo2 under Ar shows four distinct features (Figure 1). A first reduction wave was observed at $1.15 \mathrm{~V}$ vs. SCE. The thin wave is indicative of a fast charge transfer and comparison to reversible couples of similar size shows that reduction is mono-electronic. It could be assigned to $\mathrm{Mo}^{\mathrm{III}} / \mathrm{Mo}^{\mathrm{II}}$ couple. Irreversibility of this wave is due to a chemical step following the initial electron transfer, most likely iodide ligand dissociation. Indeed, oxidation waves at 0.33 and

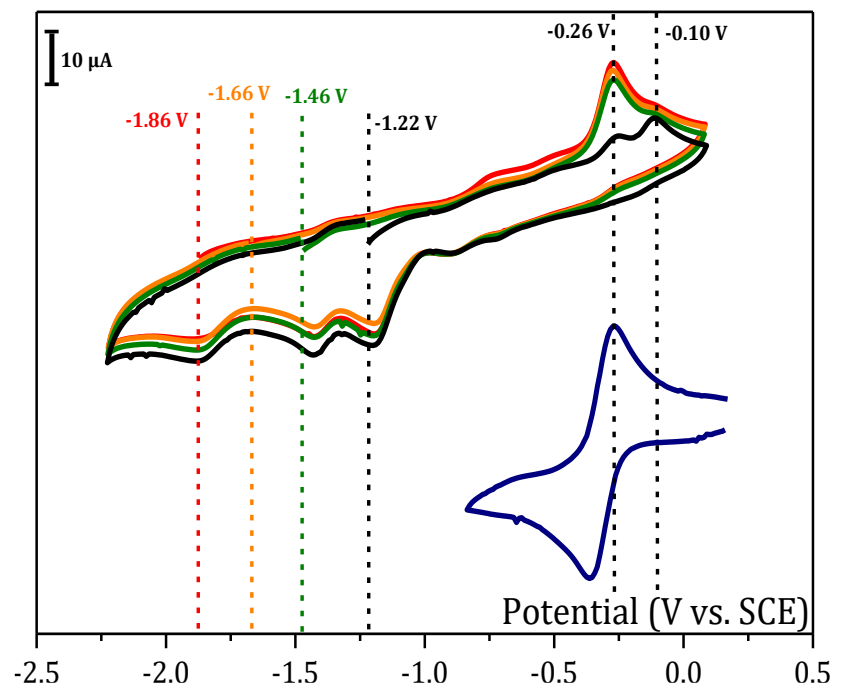

Figure 2. $\mathrm{CVs}$ of $\mathrm{Mo2}(1 \mathrm{mM})$ in $\mathrm{THF}+0.1 \mathrm{M} \mathrm{Bu}_{4} \mathrm{~N}\left[\mathrm{BAr}^{\mathrm{F}}{ }_{4}\right]$ under $\mathrm{N}_{2}$ atm, at $v=500 \mathrm{mV} / \mathrm{s}$ and RT. The starting potential was held for $15 \mathrm{~s}$ (black, green, orange and red). Blue trace: $\mathrm{CV}$ of $\operatorname{Mo3}(1.12 \mathrm{mM})$ in $\mathrm{THF}+0.1 \mathrm{M} \mathrm{Bu}_{4} \mathrm{~N}\left[\mathrm{BAr}^{\mathrm{F}}{ }_{4}\right]$ under $\mathrm{N}_{2}$ atm., at $v=500 \mathrm{mV} / \mathrm{s}$, RT. 
$0.61 \mathrm{~V}$ vs. SCE are observed, corresponding to $\mathrm{I}^{-}$oxidation to $\mathrm{I}_{2}$ and $\mathrm{I}_{3}^{-}$respectively. A second irreversible wave is located at $-1.8 \mathrm{~V}$ vs. SCE (Figure 1, pc3). It may be noted that great care should be taken in the choice of supporting electrolyte anion. The classical hexafluorophosphate $\left(\mathrm{PF}_{6}{ }^{-}\right)$does coordinate to Mo, preventing any further reactivity with $\mathrm{N}_{2}$. The bulky tetrakis(3,5-bis(trifluoromethyl)phenylborate $\left(\mathrm{BAr}_{4}^{\mathrm{F}}{ }^{-}\right)$is noncoordinating and should be preferred.

Under an atmosphere of $\mathrm{N}_{2}$, the cyclic voltammetry of Mo2 shows additional features. A new reduction peak appears at $1.40 \mathrm{~V} v s$. SCE (Figure 1, pc2), along with a related oxidation peak at $-0.26 \mathrm{~V} v s$. SCE (Figure 1, pa). This later peak is only observed when the potential is scanned until pc2, thus it corresponds to the oxidation of a species formed at this later wave. Both waves are diffusion limited. The irreversible pc3 wave is not affected by the presence of $\mathrm{N}_{2}$ (this later reduction will not be further investigated.). On the contrary, intensity of the first reduction peak (Figure 1, pc1) increases slightly and the peak potential is positively shifted, suggesting possible coordination to dinitrogen. The initial electrochemical behavior could be restored upon Ar bubbling.

To identify the species formed at pc2 and oxidized at pa, CVs of an authentic sample of $\mathbf{M o 3}$ were recorded in the same conditions. Oxidation of this complex occurs at the exact same potential as the species formed at pc2, as shown in Figure 2. This indicates the likely formation of the nitride complex Mo3 at pc2 reductive wave.

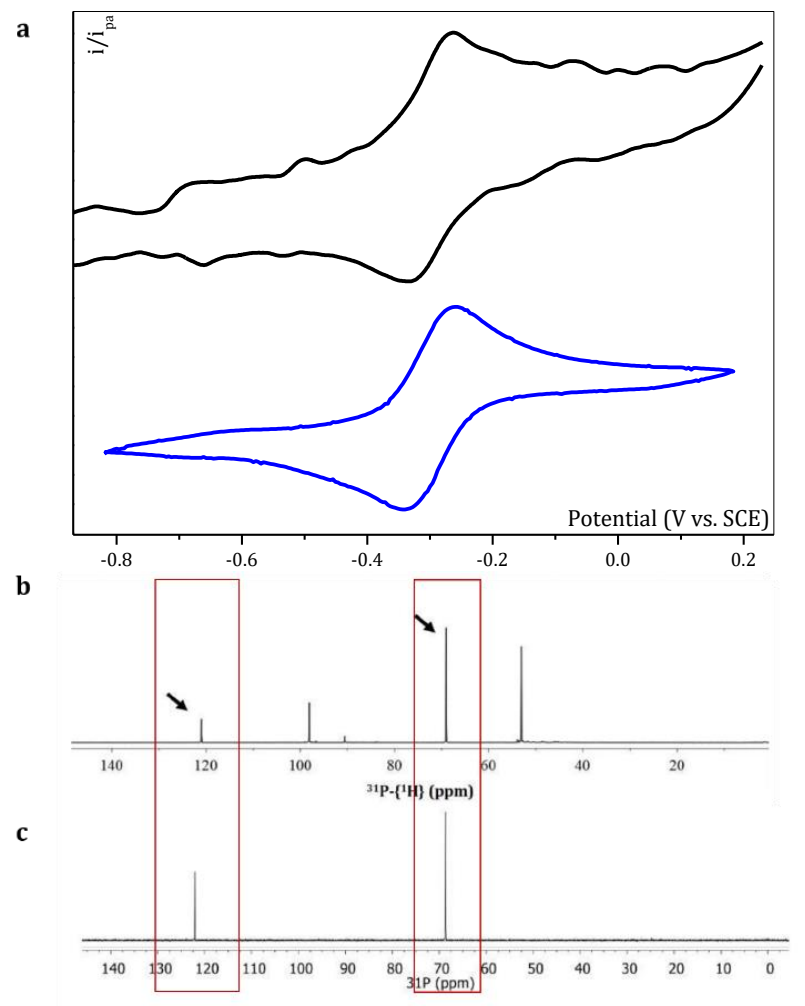

Figure 3. a) $\mathrm{CV}$ at $1 \mathrm{~mm} \mathrm{GC}$ disk of the electrolyte solution after CPE (black) and CV at $3 \mathrm{~mm}$ GC disk of $\mathbf{M o 3}(1.12 \mathrm{mM})$ in $\mathrm{THF}+0.1 \mathrm{M} \mathrm{Bu}_{4} \mathrm{~N}\left[\mathrm{BAr}_{4}{ }_{4}\right]$ under $\mathrm{N}_{2}$ atm., at $v=100 \mathrm{mV} / \mathrm{s}$, RT. b) ${ }^{31} \mathrm{P}\left\{{ }^{1} \mathrm{H}\right\}$ NMR of the same electrolyte solution. c) ${ }^{31} \mathrm{P}\left\{{ }^{1} \mathrm{H}\right\}$ NMR of complex Mo3 in THF d-8.
Scheme 3. Plausible mechanism for electrochemical reduction of $\mathrm{N}_{2}$ with (PPP) $\mathrm{MoI}_{3}$ (Mo2) complex.

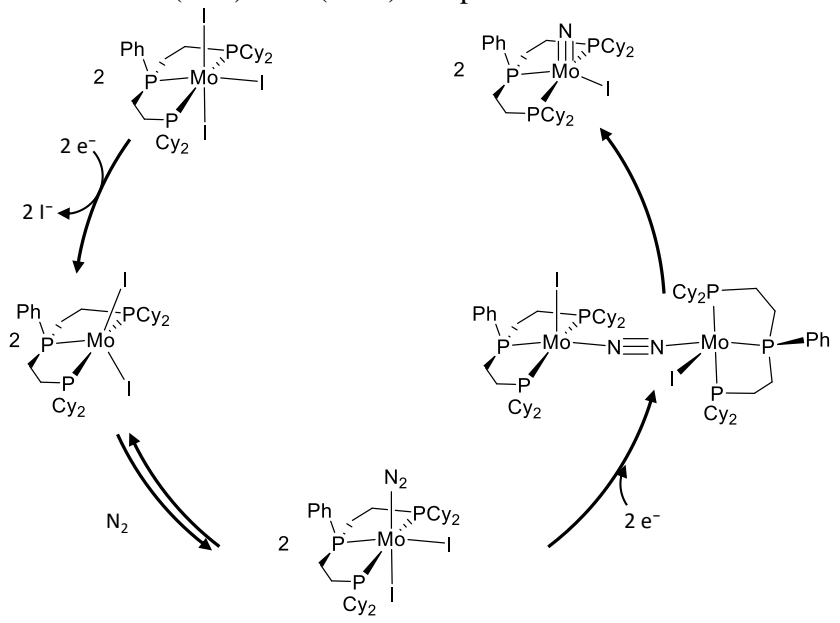

To further investigate and demonstrate $\mathrm{N}_{2}$ reductive splitting, a controlled potential electrolysis (CPE) of a THF solution $(+0.1$ $\mathrm{M} \mathrm{Bu}_{4} \mathrm{~N}\left[\mathrm{Bar}_{4}{ }_{4}\right]$ ) containing $\mathbf{M o 2}$ and saturated with $\mathrm{N}_{2}$ was performed at $-1.4 \mathrm{~V} v$ s. SCE, i.e. at $\mathrm{pc} 2$ peak potential. After a few minutes, coloration of the electrolyte solution changed from orange to greenish. After $35 \mathrm{~min}$, a charge of $1.03 \mathrm{C}$ was exchanged, corresponding to $1.24 \mathrm{e}^{-}$per Mo centre (see Supporting Information for details). At the end of the electrolysis, cyclic voltammetry of the electrolyte solution was performed (Figure 3). The oxidation waves observed at $c a$. 0.5 and $0.75 \mathrm{~V} v$. SCE correspond to oxidation of iodide ions to $\mathrm{I}_{2}$ and $\mathrm{I}_{3}{ }^{-}$and the reduction wave at $c a$. $-1.75 \mathrm{~V} v s$. SCE corresponds to the same process characterized by the wave pc3 in Figure 1. Most importantly, a new reversible wave is observed at $-0.31 \mathrm{~V} v s$. SCE. This wave corresponds to the reversible oxidation of $\mathrm{Mo}^{\mathrm{IV}}$ nitride complex Mo3, generated electrochemically during the CPE. Indeed, comparison with CVs of an authentic sample of Mo3 yields a reversible wave at the exact same potential (Figure 3a).

${ }^{31} \mathrm{P}-\mathrm{NMR}$ provided further characterization of the nitride complex. ${ }^{38}$ After the CPE, the electrolyte solution was concentrated in a J-Young NMR tube, and a small volume of deuterated THF was added. Figure $3 \mathrm{~b}$ shows two singlet peaks at 69 and 121 ppm respectively, which are characteristic of complex $\mathbf{M o 3}$ as deduced from comparison with the ${ }^{31} \mathrm{P}\left\{{ }^{1} \mathrm{H}\right\}$ spectrum of an authentic sample Mo3. The two additional singlet peaks observed at 53 and 98 ppm also correspond to a high oxidation state complex and are nearly identical to the spectral signature of the Mooxo complex [(PPP)Mo $\left.=\mathrm{O}(\mathrm{Cl})_{2}\right](53.2$ and $98.7 \mathrm{ppm}$ respectively). This later species is likely formed during electrolysis.

When the same electrolysis experiment was repeated under an Ar atmosphere, neither the reversible wave at $-0.31 \mathrm{~V} v s$. SCE in cyclic voltammetry, nor the signals at 69 and $121 \mathrm{ppm}$ in ${ }^{31} \mathrm{P}\left\{{ }^{1} \mathrm{H}\right\}$ NMR were observed. On the other hand, the oxo complex is formed efficiently under these conditions (see ESI). Understanding the precise mechanism of formation of this complex is beyond the scope of the present work, and is currently studied in our laboratories. Nonetheless, preliminary experiments indicate that both $\mathrm{O}_{2}$ and $\mathrm{H}_{2} \mathrm{O}$ can be ruled out as the source of "oxygen" for the oxo species. 
Scheme 4. DFT mechanistic insights into reductive $\mathrm{N}_{2}$ splitting with Mo3.
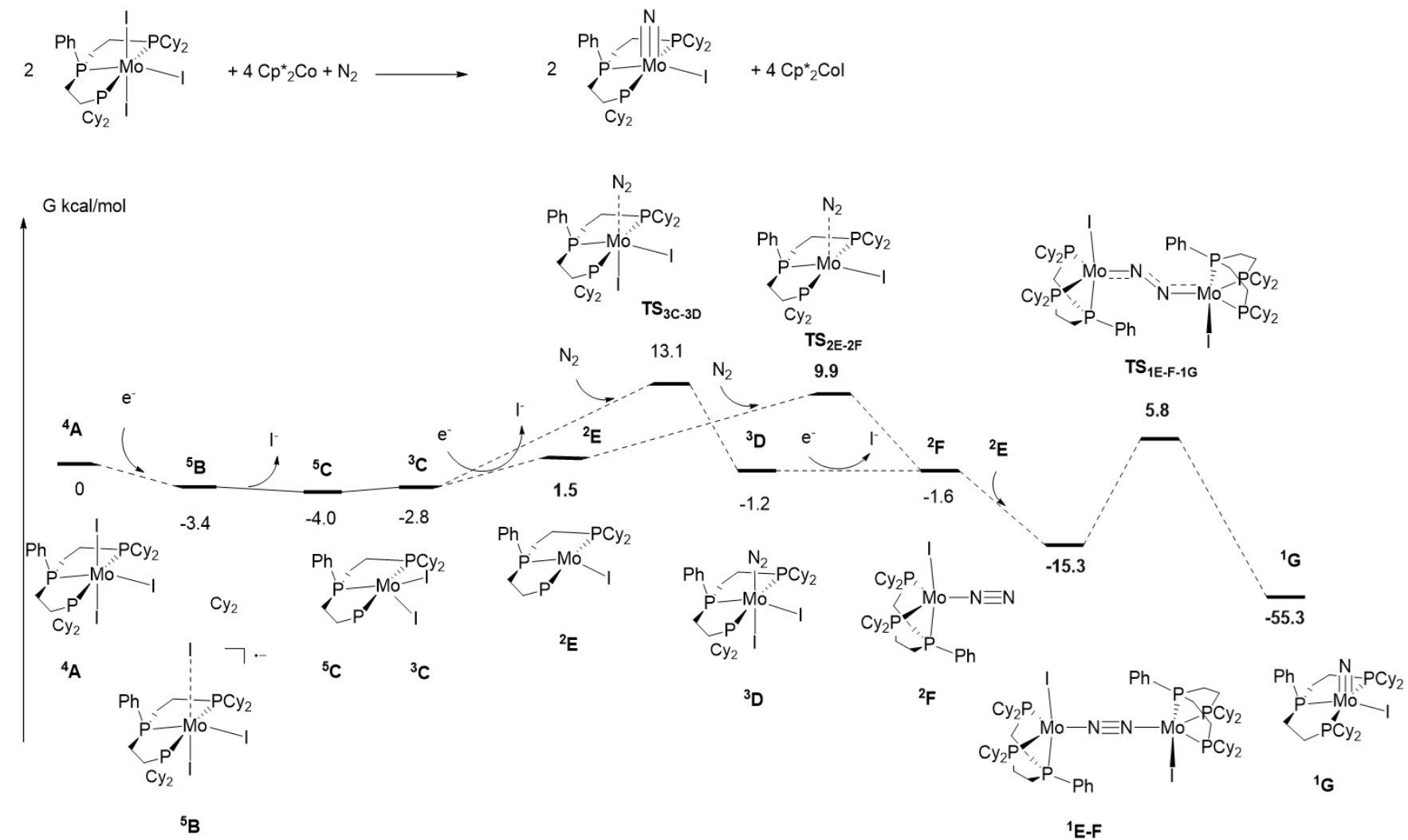

Combined $\mathrm{CV}$ and ${ }^{31} \mathrm{P}$ NMR data converge to the robust conclusion that Mo3 is obtained from Mo2 and dinitrogen upon electrochemical reduction. The yield of the reaction could be derived from cyclic voltammetry by comparing the intensity of the observed reversible wave at $-0.31 \mathrm{~V}$ after CPE with a CV recorded in the same electrolyte conditions, before CPE. The yield was found to be $c a .30 \%$. This is in agreement with the charge passed during the electrolysis (1.24 $\mathrm{e}^{-}$per Mo). Full conversion of Mo2 to Mo3 would require $2 \mathrm{e}^{-}$per Mo centre, and it was already apparent it was not the case upon inspection of cyclic voltammetry data (Figures 1 and 2). Indeed, the intensity of the pc2 wave, at which $\mathbf{M o 3}$ is produced, is significantly smaller than that of the one electron pc1 wave.

Preliminary DFT calculations were carried out to get insights into the reaction mechanism (Scheme 4, see ESI for details). Relative energies between Mo complexes with different redox states were estimated using $\mathrm{Cp} *{ }_{2} \mathrm{Co}$ as a one electron reducing agent. The lowest potential energy surface (PES) (lowest energy complexes with corresponding spin state) is presented. Complexes in different spin states have been computed and are mentioned when relevant. Calculations start with the [(PPP) $\left.\mathrm{MoI}_{3}\right]$ complex ${ }^{4} \mathbf{A}$, a quartet of spin. One electron reduction leads to the anionic complex ${ }^{5} \mathbf{B}$ (quintet of spin) in a mildly exergonic process $\left(-3.4 \mathrm{kcal} \mathrm{mol}^{-1}\right)$. Interestingly, one of the Mo-I apical bonds is strongly elongated in ${ }^{5} \mathbf{B}(5.38 \AA)$, and thus the unsaturated complex ${ }^{5} \mathbf{C}\left[(\mathrm{PPP}) \mathrm{MoI}_{2}\right]$ lies close in energy ($0.6 \mathrm{kcal} \mathrm{mol}^{-1}$ with respect to $\left.{ }^{5} \mathbf{B}\right)$. Calculations could not locate a local extremum associated to $\mathrm{N}_{2}$ coordination to ${ }^{5} \mathrm{C}$. As observed in the tri-iodide structure, octahedral geometry is not favored with a quintet spin state (Mo... $\mathrm{N}_{2}$ distance of $4.45 \AA$ ). However, the complex ${ }^{3} \mathbf{C}$ with a triplet spin state lies slightly above ${ }^{5} \mathbf{C}\left(-2.8\right.$ and $-4.0 \mathrm{kcal} \mathrm{mol}^{-1}$ resp.) and coordination of

$\mathrm{N}_{2}$ to this complex is a kinetically facile step. Indeed, the transition state $\mathbf{T S}\left({ }^{3} \mathbf{C}-{ }^{3} \mathbf{D}\right)$ is located only $15.9 \mathrm{kcal} \mathrm{mol}^{-1}$ higher than ${ }^{3} \mathbf{C}$. Dinitrogen Mo(II) complex ${ }^{3} \mathbf{D}$ is only $1.6 \mathrm{kcal} \mathrm{mol}^{-1}$ higher than ${ }^{3} \mathbf{C}$, and these two complexes are therefore in equilibrium. Splitting of $\mathrm{N}_{2}$ was evaluated at the $\mathrm{Mo}^{\mathrm{II}}$ redox state. Reaction between ${ }^{3} \mathbf{C}$ and ${ }^{3} \mathbf{D}$ to form a dimer ${ }^{3} \mathbf{C}-\mathbf{D}$ (triplet spin state) or ${ }^{1} \mathbf{C}$-D (singlet spin state) is computed to be endergonic with respect to ${ }^{3} \mathbf{C}$ and ${ }^{3} \mathbf{D}\left(\Delta G=9.6 \mathrm{kcal} \mathrm{mol}^{-1},{ }^{\mathbf{1}} \mathbf{C}-\mathbf{D} ; \Delta G=4.9\right.$ kcal $\left.\mathrm{mol}^{-1},{ }^{3} \mathbf{C}-\mathbf{D}\right)$. Moreover, calculations of the transition states for $\mathrm{N}_{2}$ cleavage for both dimers resulted in very high activation energies $\left(\Delta G^{\#}=52.0 \mathrm{kcal} \mathrm{mol}^{-1}\right.$, from ${ }^{1} \mathbf{C}-\mathbf{D} ; \Delta G^{\#}=37.3 \mathrm{kcal}$ $\mathrm{mol}^{-1}$, from ${ }^{3} \mathbf{C}$-D), and such pathway can be discarded.

One electron reduction of ${ }^{3} \mathbf{C}$ and ${ }^{3} \mathbf{D}$ is computed to be endoergic by $\Delta G=5.4 \mathrm{kcal} \mathrm{mol}^{-1}$ and $\Delta G=6.1 \mathrm{kcal} \mathrm{mol}^{-1}$, respectively. The reduced species are more stable as doublet spin states and iodide dissociation yields the mono-iodo complex [(PPP)MoI] $\left({ }^{2} \mathbf{E}\right)$ and ${ }^{2} \mathbf{F}$ from coordination to $\mathrm{N}_{2}$. The combined reduction / iodide dissociation is computed to be endoergic in the case of ${ }^{3} \mathbf{C} \rightarrow{ }^{2} \mathbf{E}+\mathrm{I}^{-}\left(\Delta G=4.3 \mathrm{kcal} \mathrm{mol}^{-1}\right)$, whereas it is slightly exoergic in the case of ${ }^{3} \mathbf{D} \rightarrow{ }^{2} \mathbf{F}+\mathrm{I}^{-}\left(\Delta G=-0.4 \mathrm{kcal} \mathrm{mol}^{-1}\right)$. Contrary to the situation encountered with $\mathrm{Mo}^{\mathrm{II}}$ center, the $\mathrm{Mo}^{\mathrm{I}}-\mathrm{N}_{2}$ complex ${ }^{2} \mathbf{F}$ is computed to be more stable than the unsaturated $\mathrm{Mo}^{\mathrm{I}}$ complex ${ }^{2} \mathbf{E}$ by $\Delta G=-3.1 \mathrm{kcal} \mathrm{mol}^{-1}$. As a result of this additional stability, the $\mathrm{N}_{2}$ coordination to ${ }^{2} \mathbf{E}$ is computed to be favorable $\left(\Delta G^{\#}=8.4 \mathrm{kcal} \mathrm{mol}^{-1}\right)$ to yield ${ }^{2} \mathbf{F}$. Formation of dimer species between ${ }^{2} \mathbf{E}$ and ${ }^{2} \mathbf{F}$, either as a singlet $\left({ }^{1} \mathbf{E}-\mathbf{F}\right)$ or as a triplet $\left({ }^{3} \mathbf{E}-\mathbf{F}\right)$ is computed to be exergonic $\left(\Delta G=-15.2 \mathrm{kcal} \mathrm{mol}^{-}\right.$ $\left.{ }^{1},{ }^{\mathbf{1}} \mathbf{E}-\mathbf{F} ; \Delta G=-15.4 \mathrm{kcal} \mathrm{mol}^{-1},{ }^{3} \mathbf{E}-\mathbf{F}\right)$. Despite being close in energy, the $\mathrm{N}_{2}$ cleavage is operative only from the singlet dimer ${ }^{\mathbf{1}} \mathbf{E}-\mathbf{F}$ with an activation barrier of $\Delta \mathrm{G}^{\#}=21.0 \mathrm{kcal} \mathrm{mol}{ }^{-1}$, whereas the process is computed to be highly unfavorable from the triplet dimer $\left(\Delta \mathrm{G}^{\#}=65.0 \mathrm{kcal} \mathrm{mol}^{-1}\right)$. The singlet transition 
state exhibits an expected zig-zag geometry with a highly elongated N-N bond (1.631 $\AA$ vs. $1.192 \AA$ in $\left.{ }^{1} \mathbf{E}-\mathbf{F}\right)$ and shorter Mo$\mathrm{N}$ contacts $(1.689 \AA$ and $1.693 \AA$ vs. $1.868 \AA$ and $1.871 \AA$ in ${ }^{\mathbf{1}} \mathbf{E}$-F). The overall transformation ${ }^{2} \mathbf{E}+{ }^{2} \mathbf{F} \rightarrow 2{ }^{\mathbf{1}} \mathbf{G}$, where ${ }^{\mathbf{1}} \mathbf{G}$ is the $\mathrm{Mo}^{\mathrm{IV}}$-nitrido (Mo3) final product resulting from $\mathrm{N}_{2}$ cleavage is computed to be strongly exoergic $\left(\Delta G=-55.3 \mathrm{kcal} \mathrm{mol}^{-}\right.$ $\left.{ }^{1}\right)$.

Overall, DFT studies support the electrochemical mechanism for $\mathrm{N}_{2}$ splitting given in Scheme 3. It involves spontaneous iodide dissociation upon one-electron reduction to form the $\mathrm{Mo}^{\text {II }}$ di-iodide intermediate in equilibrium with the $\mathrm{N}_{2}$-coordinated $\mathrm{Mo}^{\mathrm{II}}$ complex. $\mathrm{Mo}^{\mathrm{II}} \mathrm{N}_{2}$-dimer formation is thermodynamically accessible but $\mathrm{N}_{2}$ cleavage is kinetically prohibited. A second reduction at more negative potential results in further iodide dissociation and easy $\mathrm{N}_{2}$ coordination to $\mathrm{Mo}^{\mathrm{I}}$, resulting in thermodynamically easy formation of $\mathrm{N}_{2}$-dimer species from which splitting to $\mathrm{Mo}^{\mathrm{IV}}$ nitride species is kinetically accessible.

In summary, we have demonstrated the electrochemical splitting of dinitrogen at a Mo molecular complex in ambient conditions, and characterized the formation of the corresponding Mo-nitride complex. To the best of our knowledge, this is the first electrochemical reduction driven splitting of $\mathrm{N}_{2}$ with molybdenum species. Such nitride complexes are ideal starting point not only for the chemical functionalization but also and most importantly for electrochemical studies aiming at generating ammonia upon successive proton-coupled electron transfers (PCET process), one step closer from molecular electrochemical catalysis of $\mathrm{N}_{2}$ reduction with metal complexes.

\section{ASSOCIATED CONTENT}

Materials and methods, supplementary CV data and NMR spectra. This material is available free of charge via the Internet at http://pubs.acs.org.

\section{AUTHOR INFORMATION}

\section{Corresponding Author}

* Email: mezailles@ chimie.ups-tlse.fr

* Email: robert@u-paris.fr

\section{ORCID}

Lydia Merakeb: 0000-0002-5834-8144

Soukaina Bennaamane: 0000-0002-5358-0585

Eric Clot: 0000-0001-8332-5545

Nicolas Mézailles: 0000-0001-8735-6285

Marc Robert: 0000-0001-7042-4106

\section{Author Contributions}

The manuscript was written through contributions of all authors. / All authors have given approval to the final version of the manuscript. $\$$ These authors contributed equally.

\section{Funding Sources}

Authors would like to acknowledge support from the Agence Nationale de la Recherche (ANR) through the program ANR-16CE07-0033-04.

\section{Notes}

The authors declare no competing financial interest.

\section{ACKNOWLEDGMENT}

Partial financial support to M.R. from the Institut Universitaire de France (IUF) is gratefully acknowledged.

\section{REFERENCES}

(1) Ferguson, S. J. Nitrogen Cycle Enzymology. Curr. Opin. Chem. Biol. 1998, 2 (2), 182-193. https://doi.org/10.1016/S1367-5931(98)80059-8.

Gruber, N.; Galloway, J. N. An Earth-System Perspective of the Global Nitrogen Cycle. Nature 2008, 451 (7176), 293-296. https://doi.org/10.1038/nature06592.

Guo, J.; Chen, P. Catalyst: NH3 as an Energy Carrier. Chem 2017, 3 (5), 709-712. https://doi.org/10.1016/j.chempr.2017.10.004.

Lan, R.; Irvine, J. T. S.; Tao, S. Ammonia and Related Chemicals as Potential Indirect Hydrogen Storage Materials. International Journal of Hydrogen Energy. Pergamon January 1, 2012, pp 1482-1494. https://doi.org/10.1016/j.ijhydene.2011.10.004.

Hoffman, B. M.; Lukoyanov, D.; Yang, Z. Y.; Dean, D. R.; Seefeldt, L. C. Mechanism of Nitrogen Fixation by Nitrogenase: The next Stage. Chem. Rev. 2014, 114 (8), 4041-4062. https://doi.org/10.1021/cr400641x.

Yandulov, D. V.; Schrock, R. R. Catalytic Reduction of Dinitrogen to Ammonia at a Single Molybdenum Center. Science (80-. ). 2003, 301, 76-78.

Wickramasinghe, L. A.; Ogawa, T.; Schrock, R. R.; Müller, P. Reduction of Dinitrogen to Ammonia Catalyzed by Molybdenum Diamido Complexes. J. Am. Chem. Soc. 2017, 139 (27), 9132-9135. https://doi.org/10.1021/jacs.7b04800.

Arashiba, K.; Miyake, Y.; Nishibayashi, Y. A Molybdenum Complex Bearing PNP-Type Pincer Ligands Leads to the Catalytic Reduction of Dinitrogen into Ammonia. Nat. Chem. 2011, 3 (2), 120-125. https://doi.org/10.1038/nchem.906.

Ashida, Y.; Arashiba, K.; Nakajima, K.; Nishibayashi, Y. Molybdenum-Catalysed Ammonia Production with Samarium Diiodide and Alcohols or Water. Nature 2019, 568 (7753), 536-540. https://doi.org/10.1038/s41586019-1134-2.

Liao, Q.; Cavaillé, A.; Saffon-Merceron, N.; Mézailles, N. Direct Synthesis of Silylamine from $\mathrm{N}_{2}$ and a Silane: Mediated by a Tridentate Phosphine Molybdenum Fragment. Angew. Chem. - Int. Ed. 2016, 55 (37), 1121211216. https://doi.org/10.1002/anie.201604812.

Silantyev, G. A.; Förster, M.; Schluschaß, B.; Abbenseth, J.; Würtele, C.; Volkmann, C.; Holthausen, M. C.; Schneider, S. Dinitrogen Splitting Coupled to Protonation. Angew. Chem. - Int. Ed. 2017, 56 (21), 5872-5876. https://doi.org/10.1002/anie.201701504.

Bennaamane, A. S.; Espada, M.; Mulas, A.; Personeni, T.; Saffon-merceron, N.; Fustier-, M.; Bucher, C.; Mézailles, N. Angew. Chem. - Int. Ed. 2021 https://doi.org/10.1002/anie.202106025.

Anderson, J. S.; Rittle, J.; Peters, J. C. Catalytic Conversion of Nitrogen to Ammonia by an Iron Model Complex. Nature 2013, 501 (7465), 84-87. https://doi.org/10.1038/nature12435.

Reiners, M.; Baabe, D.; Münster, K.; Zaretzke, M. K.; Freytag, M.; Jones, P. G.; Coppel, Y.; Bontemps, S.; Rosal, I. del; Maron, L.; Walter, M. D. NH3 Formation from N2 and H2 Mediated by Molecular Tri-Iron Complexes. Nat. Chem. 2020, 12 (8), 740-746. https://doi.org/10.1038/s41557-020-0483-7.

Ferreira, R. B.; Cook, B. J.; Knight, B. J.; Catalano, V. J.; García-Serres, R.; Murray, L. J. Catalytic Silylation of 
Dinitrogen by a Family of Triiron Complexes. ACS Catal. 2018, $\quad 8 \quad$ (8), 7208-7212. https://doi.org/10.1021/acscatal.8b02021.

(16) McWilliams, S. F.; Holland, P. L. Dinitrogen Binding and Cleavage by Multinuclear Iron Complexes. Acc. Chem. Res. 2015, 48 (7), 2059-2065. https://doi.org/10.1021/acs.accounts.5b00213.

(17) Klopsch, I.; Finger, M.; Würtele, C.; Milde, B.; Werz, D. B.; Schneider, S. Dinitrogen Splitting and Functionalization in the Coordination Sphere of Rhenium. J. Am. Chem. Soc. 2014, 136 (19), 6881-6883. https://doi.org/10.1021/ja502759d.

(18) Lindley, B. M.; Van Alten, R. S.; Finger, M.; Schendzielorz, F.; Würtele, C.; Miller, A. J. M.; Siewert, I.; Schneider, S. Mechanism of Chemical and Electrochemical N 2 Splitting by a Rhenium Pincer Complex. J. Am. Chem. Soc. 2018, 140 (25), 7922-7935. https://doi.org/10.1021/jacs.8b03755.

(19) Bruch, Q. J.; Connor, G. P.; Chen, C. H.; Holland, P. L.; Mayer, J. M.; Hasanayn, F.; Miller, A. J. M. Dinitrogen Reduction to Ammonium at Rhenium Utilizing Light and Proton-Coupled Electron Transfer. J. Am. Chem. Soc. 2019, $\quad 141 \quad$ (51), 20198-20208. https://doi.org/10.1021/jacs.9b10031.

(20) Sekiguchi, Y.; Arashiba, K.; Tanaka, H.; Eizawa, A.; Nakajima, K.; Yoshizawa, K.; Nishibayashi, Y. Catalytic Reduction of Molecular Dinitrogen to Ammonia and Hydrazine Using Vanadium Complexes. Angew. Chemie - Int. Ed. 2018, 57 (29), 9064-9068. https://doi.org/10.1002/anie.201802310.

(21) Kendall, A. J.; Johnson, S. I.; Bullock, R. M.; Mock, M. T. Catalytic Silylation of N2 and Synthesis of NH3 and N2H4 by Net Hydrogen Atom Transfer Reactions Using a Chromium P4 Macrocycle. J. Am. Chem. Soc. 2018, 140 (7), 2528-2536. https://doi.org/10.1021/jacs.7b11132.

(22) Shima, T.; Yang, J.; Luo, G.; Luo, Y.; Hou, Z. Dinitrogen Activation and Hydrogenation by C5Me4SiMe3-Ligated Di- And Trinuclear Chromium Hydride Complexes. $J$. Am. Chem. Soc. 2020, 142 (19), 9007-9016. https://doi.org/10.1021/jacs.0c02939.

(23) Kendall, A. J.; Mock, M. T. Dinitrogen Activation and Functionalization with Chromium. Eur. J. Inorg. Chem. 2020, $2020 \quad$ (15-16), 1358-1375 https://doi.org/10.1002/ejic.201901257.

(24) Kuriyama, S.; Arashiba, K.; Tanaka, H.; Matsuo, Y.; Nakajima, K.; Yoshizawa, K.; Nishibayashi, Y. Direct Transformation of Molecular Dinitrogen into Ammonia Catalyzed by Cobalt Dinitrogen Complexes Bearing Anionic PNP Pincer Ligands. Angew. Chem. - Int. Ed. 2016, 55 (46), 14291-14295. https://doi.org/10.1002/anie.201606090.

(25) Suzuki, T.; Fujimoto, K.; Takemoto, Y.; Wasada-Tsutsui, Y.; Ozawa, T.; Inomata, T.; Fryzuk, M. D.; Masuda, H. Efficient Catalytic Conversion of Dinitrogen to $\mathrm{N}(\mathrm{SiMe} 3) 3$ Using a Homogeneous Mononuclear Cobalt Complex. ACS Catal. 2018, 8 (4), 3011-3015. https://doi.org/10.1021/acscatal.7b04351.

(26) Doyle, L. R.; Wooles, A. J.; Jenkins, L. C.; Tuna, F.; McInnes, E. J. L.; Liddle, S. T. Catalytic Dinitrogen Reduction to Ammonia at a Triamidoamine-Titanium Complex. Angew. Chem. - Int. Ed. 2018, 57 (21), 63146318. https://doi.org/10.1002/anie.201802576.
Ostermann, N.; Siewert, I. Electrochemical N2 Splitting at Well-Defined Metal Complexes. Curr. Opin. Electrochem. 2019, 15, 97-101. https://doi.org/10.1016/j.coelec.2019.04.024.

(28) Bruch, Q. J.; Connor, G. P.; McMillion, N. D.; Goldman, A. S.; Hasanayn, F.; Holland, P. L.; Miller, A. J. M. Considering Electrocatalytic Ammonia Synthesis via Bimetallic Dinitrogen Cleavage. ACS Catal. 2020, 10 (19), 10826-10846. https://doi.org/10.1021/acscatal.0c02606.

(29) Chalkley, M. J.; Drover, M. W.; Peters, J. C. Catalytic N2to-NH3(or -N2H4) Conversion by Well-Defined Molecular Coordination Complexes. Chem. Rev. 2020, $120 \quad$ (12), 5582-5636. https://doi.org/10.1021/acs.chemrev.9b00638.

(30) Pickett, C. J.; Talarmin, J. Electrosynthesis of Ammonia. $\begin{array}{llll}\text { Nature } & 1985, & 317 & \text { (6038), 652-653. }\end{array}$ https://doi.org/10.1038/317652a0.

(31) Jeong, E. Y.; Yoo, C. Y.; Jung, C. H.; Park, J. H.; Park, Y. C.; Kim, J. N.; Oh, S. G.; Woo, Y.; Yoon, H. C. Electrochemical Ammonia Synthesis Mediated by Titanocene Dichloride in Aqueous Electrolytes under Ambient Conditions. ACS Sustain. Chem. Eng. 2017, 5 (11), 9662-9666. https://doi.org/10.1021/acssuschemeng.7b02908.

(32) Sherbow, T. J.; Thompson, E. J.; Arnold, A.; Sayler, R. I.; Britt, R. D.; Berben, L. A. Electrochemical Reduction of $\mathrm{N} 2$ to NH3 at Low Potential by a Molecular Aluminum Complex. Chem. - A Eur. J. 2019, 25 (2), 454-458. https://doi.org/10.1002/chem.201804454.

(33) Del Castillo, T. J.; Thompson, N. B.; Peters, J. C. A Synthetic Single-Site Fe Nitrogenase: High Turnover, Freeze-Quench 57Fe Mössbauer Data, and a Hydride Resting State. J. Am. Chem. Soc. 2016, 138 (16), 53415350. https://doi.org/10.1021/jacs.6b01706.

(34) Saha, P.; Amanullah, S.; Dey, A. Electrocatalytic Reduction of Nitrogen to Hydrazine Using a Trinuclear Nickel Complex. J. Am. Chem. Soc. 2020, 142 (41), 17312-17317. https://doi.org/10.1021/jacs.0c08785.

(35) van Alten, R. S.; Wätjen, F.; Demeshko, S.; Miller, A. J. M.; Würtele, C.; Siewert, I.; Schneider, S. (ElectroChemical Splitting of Dinitrogen with a Rhenium Pincer Complex. Eur. J. Inorg. Chem. 2020, 2020 (15-16), 1402 1410. https://doi.org/10.1002/ejic.201901278

(36) Katayama, A.; Ohta, T.; Wasada-Tsutsui, Y.; Inomata, T.; Ozawa, T.; Ogura, T.; Masuda, H. DinitrogenMolybdenum Complex Induces Dinitrogen Cleavage by One-Electron Oxidation. Angew. Chem. - Int. Ed. 2019, 58, 11279-11284. https://doi.org/10.1002/anie.201905299 Bennaamane, S.; Espada, M. F.; Yagoub, I.; SaffonMerceron, N.; Nebra, N.; Fustier-Boutignon, M.; Clot, E.; Mézailles, N. Stepwise Functionalization of $\mathrm{N}_{2}$ at Mo: Nitrido to Imido to Amido - Factors Favoring Amine Elimination from the Amido Complex. Eur. J. Inorg. Chem. 2020, 2020 (15-16), 1499-1505. https://doi.org/https://doi.org/10.1002/ejic.201901295.

(38) Meek, D. W.; Mazanec, T. J. Determination of Structural and Dynamic Aspects of Organometallic and Coordination Chemistry by Phosphorus-31 NMR Spectroscopy. Acc. Chem. Res. 1981, 14 (9), 266-274. https://doi.org/10.1021/ar00069a002. 
Supporting information

\section{Molecular Electrochemical Reductive Splitting of Dinitrogen with a Molybdenum Complex}

Lydia Merakeb $^{\mathrm{a}}$, Soukaina Bennaamane ${ }^{\mathrm{b}}$, Eric Clot,${ }^{\mathrm{c}}$ Nicolas Mézailles $^{\mathrm{b} *}$ and Marc Robert ${ }^{\mathrm{a}, \mathrm{d}^{*}}$

a'Université de Paris, Laboratoire d'Electrochimie Moléculaire, CNRS, F-75006 Paris, France

bLaboratoire Hétérochimie Fondamentale et Appliquée - UMR 5069, Université Toulouse III - Paul Sabatier, 118, route de Narbonne, Bât. 2R1, 31062, Toulouse, France

'ICGM, Univ Montpellier, CNRS, ENSCM, Montpellier, France

${ }^{\mathrm{d} I n s t i t u t}$ Universitaire de France (IUF), F-75005, Paris, France 


\section{Contents}

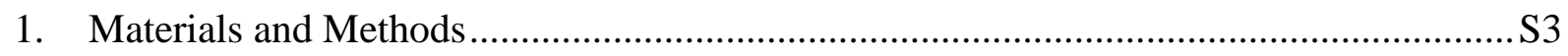

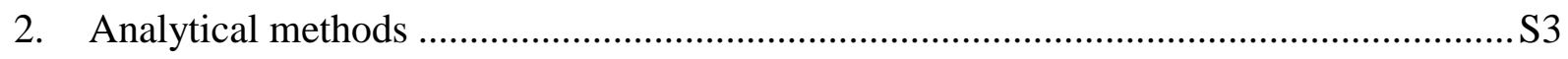

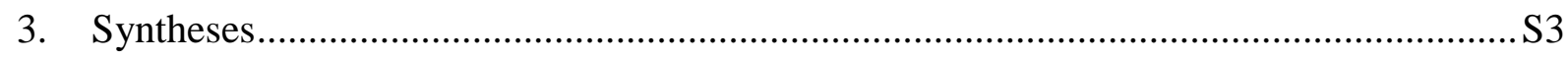

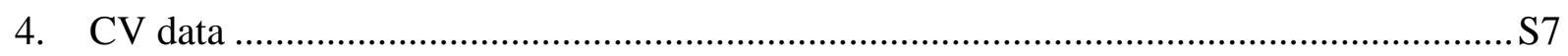

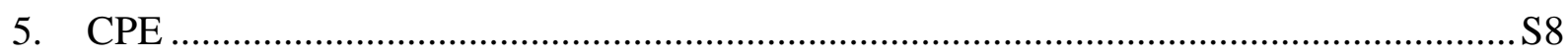

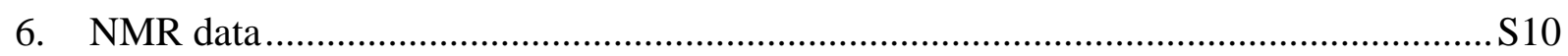

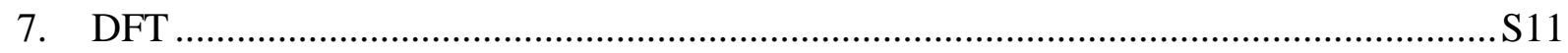

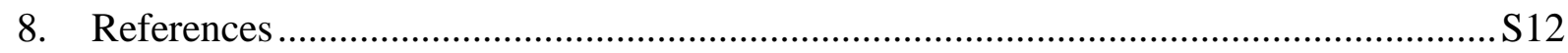




\section{Materials and Methods}

All experiments were performed under either $\mathrm{Ar}$ or $\mathrm{N}_{2}$ atmosphere using a glove-box and standard Schlenk-line techniques. THF, $\mathrm{Et}_{2} \mathrm{O}$ and DCM (HPLC grade) were purchased from VWR. THF and $\mathrm{Et}_{2} \mathrm{O}$ were distilled and further dried over $3 \AA$ molecular sieves for at least $48 \mathrm{~h}$ before use. DCM was distilled over $\mathrm{CaH}_{2}$. Deuterated solvents were purchased from Eurisotop and THF-d8 was dried over 3 $\AA ̊ n$ molecular sieves. ACN (99.9\% extra dry over molecular sieves) was purchased from Acros Organics and was further dried over an activated alumina column (neutral Brockman Activity I) before use. Ar and $\mathrm{N}_{2}$ (alphagaz 2, Air Liquide) were further dried over $\mathrm{CaCl}_{2}$ when not used in the glove-box.

\section{Analytical methods}

Spectroscopy. NMR spectra were recorded on a Bruker $400 \mathrm{MHz}$ spectrometer. ${ }^{1} \mathrm{H}$ spectra were calibrated using the residual solvent signals and ${ }^{31} \mathrm{P}$ spectra were reported relative to phosphoric acid as external standard.

Electrochemistry. All electrochemical data were collected on a Metrohm Autolab instrument. For CV measurements, the working electrode was a homemade $3 \mathrm{~mm}$ glassy carbon disk (Tokai) sealed in glass. It was carefully polished using diamond paste $(1 \mu \mathrm{m})$, rinsed with acetone and dried before each use. The platinum thread counter-electrode was flame annealed before use. The reference electrode was a non-aqueous $\mathrm{Ag} / \mathrm{AgNO}_{3}$ quasi-reference electrode, composed of a flame annealed $\mathrm{Ag}$ thread in acetonitrile containing $0.1 \mathrm{M} \mathrm{Bu}_{4} \mathrm{NPF}_{6}$ and $0.01 \mathrm{M} \mathrm{AgNO}_{3}$ in a Vycor tip terminated bridge. It was separated from the working electrode compartment by a fritted glass bridge. The exact potential of this reference vs. SCE was measured using a multimeter before and after each experiments. Potentials are referred to SCE in all figures. Ohmic drop was compensated using the positive feedback implemented in the instrument.

In Controlled Potential Electrolyses (CPEs), the working electrode was a polished $1 \mathrm{~cm}^{2}$ carbon plate, whose surface was defined using Teflon tape. The counter-electrode was a flame annealed Pt grid in THF containing $0.1 \mathrm{M} \mathrm{Bu}_{4} \mathrm{~N}\left[\mathrm{BAr}_{4}{ }_{4}\right]$ and $100 \mathrm{mM}$ ferrocene as a sacrificial oxidation substrate and the reference electrode was a non-aqueous $\mathrm{Ag} / \mathrm{AgNO}_{3}$ electrode. Both $\mathrm{CE}$ and $\mathrm{RE}$ were separated from the main compartment by two fritted glass bridges. The electrolyte solution was kept under forced convection with a magnetic stirrer.

\section{Syntheses}

Synthesis of Mo2 and Mo3 Mo3 was synthesized following a reported procedure. ${ }^{1}$ Mo2 was prepared as follows:

$\left[\mathrm{MoI}_{3}(\mathrm{THF})_{3}\right]^{2}(100 \mathrm{mg}, 0,146 \mathrm{mmol})$ was dissolved in $20 \mathrm{~mL}$ THF and stirred for a few minutes. Then $0.86 \mathrm{~mL}$ of a solution of $\mathrm{P}^{\mathrm{Ph}} \mathrm{P}_{2}{ }^{\mathrm{Cy}}$ in THF $(0,17 \mathrm{M}, 0,146 \mathrm{mmol})$ was added and the mixture was stirred for 24 hours at room temperature. The solution turns from dark red to orange and Mo2 starts precipitating as an orange powder. The solvent is then evacuated in vacuo and the powder is washed twice with pentane and dried under vacuum. Isolated yield: $134 \mathrm{mg}, 89 \%$. MALDI-TOF: calculated for C34H57I2MoP3: 910,08; found: 910,11. 
Synthesis of $\mathrm{Bu}_{4} \mathrm{~N}\left[\mathrm{BAr}_{4}{ }_{4}\right]$ and $\mathrm{Na}_{[}\left[\mathrm{BAr}_{4}{ }_{4}\right] \quad$ Sodium n-tetrabutylammonium tetrakis(3,5-bis (trifluoromethyl)phenyl) borate was synthesized by metathesis of sodium tetrakis (3,5-bis (trifluoromethyl)phenyl) borate with n-tetrabutylammonium chloride. $\mathrm{Na}\left[\mathrm{BAr}{ }_{4}{ }^{\mathrm{F}}\right.$ ] was dissolved in a minimal amount of milliQ water, to which methanol was added till the salt was completely dissolved. 1.05 eq. of $\mathrm{Bu}_{4} \mathrm{Cl}$ were also dissolved in a minimal amount of water, and added dropwise, under vigorous stirring. $\mathrm{Bu}_{4} \mathrm{~N}\left[\mathrm{BAr}_{4}\right]$ formed immediately as a white precipitate. It was then collected by filtration, rinsed several times with milliQ water and dried at $80{ }^{\circ} \mathrm{C}$ under vacuum for 48 hours.

$\mathrm{Na}\left[\mathrm{BAr}_{4}{ }_{4}\right]$ was synthesized following a reported procedure. ${ }^{3}$

\section{Synthesis and characterization of the oxo complex $\left[\mathrm{Mo}\left(\mathrm{P}^{\mathrm{Ph}} \mathrm{P}_{2}{ }^{\mathrm{Cy}}\right)(\mathrm{Cl} 2)(\mathrm{O})\right]\left(\left[\mathrm{PPPMo}=\mathrm{O}(\mathrm{Cl})_{2}\right]\right)$}

$\left[\mathrm{Mo}\left(\mathrm{P}^{\mathrm{Ph}} \mathrm{P}_{2}{ }^{\mathrm{Cy}}\right)\left(\mathrm{Cl}_{3}\right)\right](\mathrm{THF})_{2}(194.0 \mathrm{mg}, 0.215 \mathrm{mmol})$ and $\mathrm{NaI}(64.6 \mathrm{mg}, 0.431 \mathrm{mmol})$ were dissolved in "wet" THF $\left(10 \mathrm{~mL}\right.$, containing ca $\left.500 \mathrm{ppm} \mathrm{H}_{2} \mathrm{O}\right)$ in a Schlenk flask. The mixture was stirred for $10 \mathrm{~min}$ at room temperature under $1 \mathrm{~atm} \mathrm{~N}_{2}$. Then Sodium amalgam was added $(0.431 \mathrm{mmol})$. After stirring 5 hours, the solution had turned from yellow to green. An aliquot was taken and analyzed in ${ }^{31} \mathrm{P}$ NMR, revealing two products, the known nitrido complex $\left[\mathrm{Mo}\left(\mathrm{P}^{\mathrm{Ph}} \mathrm{P}_{2}{ }^{\mathrm{Cy}}\right) \mathrm{NI}\right]$ as a minor product and a new diamagnetic compound as the major product. The solution mixture was filtered then the solvent was partially evacuated in vacuo. The obtained concentrated solution was placed in vial and a couple of drops of pentane were added slowly, then the vial was kept at $-30^{\circ} \mathrm{C}$. After 2 days, green crystals were obtained in $70 \%$ yield. The X-Ray diffraction analysis showed these crystals to be the oxo complex $\left[\mathrm{Mo}\left(\mathrm{P}^{\mathrm{Ph}} \mathrm{P}_{2}{ }^{\mathrm{Cy}}\right)\left(\mathrm{Cl}_{2}\right)(\mathrm{O})\right]$.

${ }^{1} \mathbf{H}$ NMR $\left(400 \mathrm{MHz}, \mathrm{THF}_{-} \mathrm{d}_{8}, 25^{\circ} \mathrm{C}\right) \delta: 7.7\left(\mathrm{~m}, 2 \mathrm{H}, 2 \mathrm{H}_{o}^{\mathrm{Ph}}\right), 7.4\left(\mathrm{~m}, 3 \mathrm{H}, \mathrm{H}_{p}{ }^{\mathrm{Ph}}, 2 \mathrm{H}_{m}{ }^{\mathrm{Ph}}\right), 2.9-0.7(\mathrm{~m}, 4$ $\left.\mathrm{CH}^{\mathrm{Cy}}, 20 \mathrm{CH}_{2}{ }^{\mathrm{Cy}}, 4 \mathrm{P}\left(\mathrm{CH}_{2}\right)_{2} \mathrm{P}\right)$ ppm.

${ }^{31} \mathbf{P}\left\{{ }^{1} \mathbf{H}\right\}$ NMR $\left(160 \mathrm{MHz}, \mathrm{THF}_{\mathrm{d}}, 25^{\circ} \mathrm{C}\right) \delta: 53.2$ (s, 2P), 98.7 (s, 1P) ppm.

MALDI-MS $(\mathrm{m} / \mathrm{z}): 742[\mathrm{M}]^{+}$

liao_q_300c.59.fid 2-23-MoPhCY2CI2O-THF-P

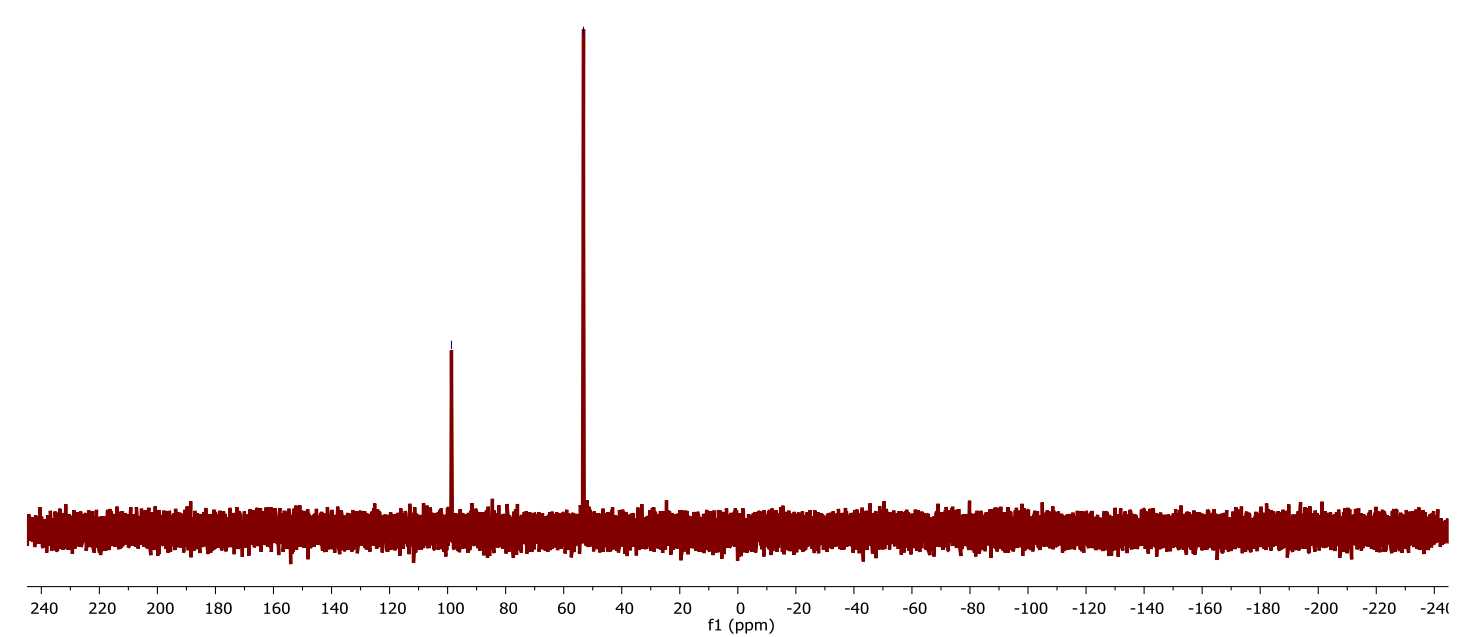

Figure S1. ${ }^{31} \mathrm{P}\left\{{ }^{1} \mathrm{H}\right\}$ NMR spectrum of $\mathrm{Mo}=\mathrm{O}$. 


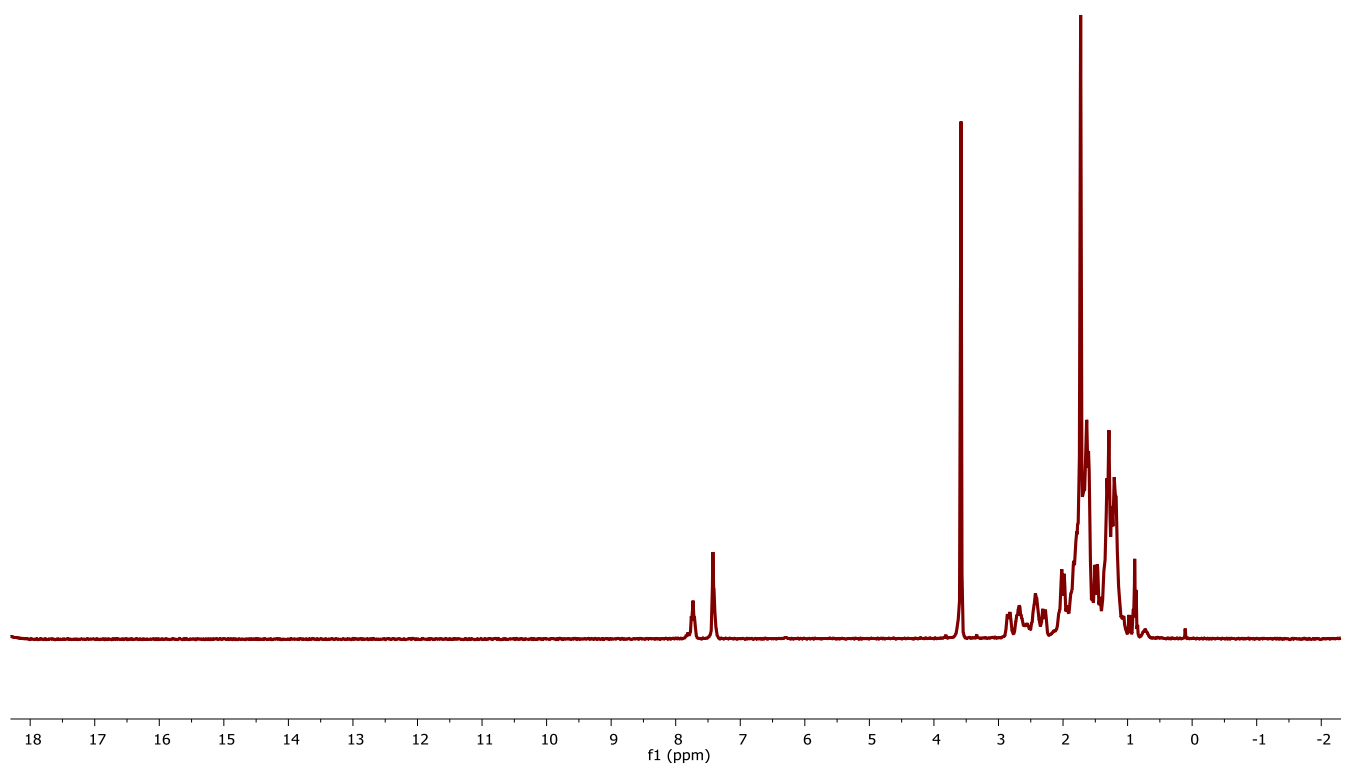

Figure S2. ${ }^{1} \mathrm{H}$ NMR spectrum of $\mathrm{Mo}=\mathrm{O}$.

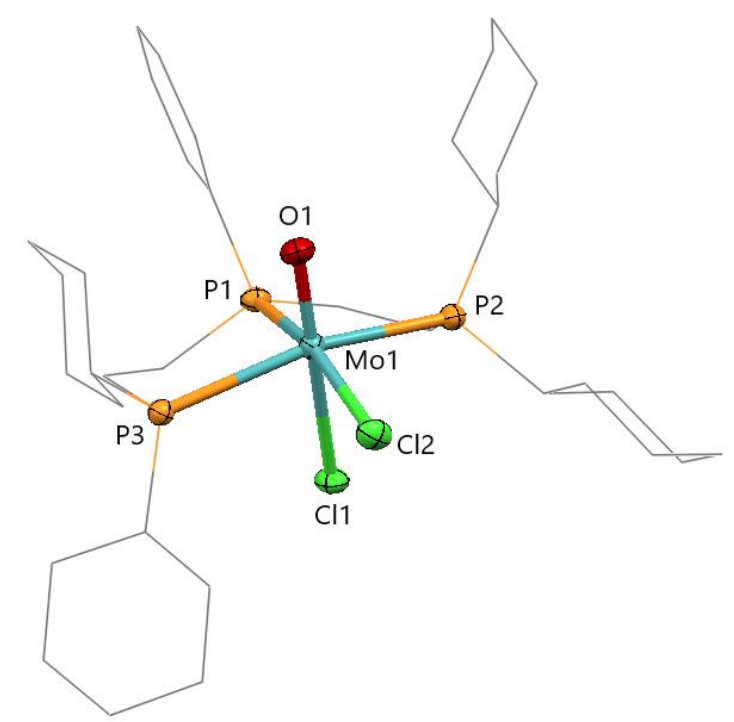

Table S1. Crystal data and structure refinement for $\mathbf{M o}=\mathbf{O}$.

Empirical formula

Formula weight

Temperature

Wavelength

Crystal system

Space group

Unit cell dimensions

Volume

Z

Density (calculated)

Absorption coefficient
C34 H57 Cl2 Mo O P3

741.54

193(2) K

$0.71073 \AA$

Monoclinic

$\mathrm{P} 21 / \mathrm{c}$

$\mathrm{a}=13.1899(6) \AA$

$\alpha=90^{\circ}$.

$\mathrm{b}=13.3861(6) \AA$

$\alpha=101.9247(16)^{\circ}$.

$\mathrm{c}=21.1229(9) \AA$

$\alpha=90^{\circ}$. 
$\mathrm{F}(000)$

Crystal size

Theta range for data collection

Index ranges

Reflections collected

Independent reflections

Completeness to theta $=25.242^{\circ}$

Absorption correction

Max. and min. transmission

Refinement method

Data / restraints / parameters

Goodness-of-fit on $\mathrm{F}^{2}$

Final $\mathrm{R}$ indices [I $>2 \operatorname{sigma}(\mathrm{I})]$

$\mathrm{R}$ indices (all data)

Extinction coefficient

Largest diff. peak and hole
1560

$0.200 \times 0.200 \times 0.160 \mathrm{~mm}^{3}$

3.157 to $33.699^{\circ}$.

$-20<=\mathrm{h}<=20,-20<=\mathrm{k}<=20,-32<=\mathrm{l}<=31$

156420

$14494[\mathrm{R}(\mathrm{int})=0.0626]$

$99.8 \%$

Semi-empirical from equivalents

0.7384 and 0.6949

Full-matrix least-squares on $\mathrm{F}^{2}$

14494 / 0 / 370

1.052

$\mathrm{R} 1=0.0364, \mathrm{wR} 2=0.0724$

$\mathrm{R} 1=0.0678, \mathrm{wR} 2=0.0850$

$\mathrm{n} / \mathrm{a}$

1.550 and -1.009 e. $\AA^{-3}$

Table S2. Selected bond lengths $[\AA]$ and angles $\left[{ }^{\circ}\right]$ for $\mathbf{M o}=\mathbf{O}$.

\begin{tabular}{llll}
\hline Bond Distances & & & \\
\hline $\mathrm{Mo}(1)-\mathrm{O}(1)$ & $1.7064(13)$ & $\mathrm{Mo}(1)-\mathrm{P}(3)$ & $2.5447(5)$ \\
$\mathrm{Mo}(1)-\mathrm{P}(1)$ & $2.4383(4)$ & $\mathrm{Mo}(1)-\mathrm{Cl}(1)$ & $2.5886(4)$ \\
$\mathrm{Mo}(1)-\mathrm{P}(2)$ & $2.4985(5)$ & $\mathrm{Mo}(1)-\mathrm{Cl}(2)$ & $2.4674(4)$ \\
& & & \\
\hline Bond Angles $\left(^{\circ}\right)$ & & $\mathrm{Cl}(2)-\mathrm{Mo}(1)-\mathrm{P}(3)$ & $95.351(15)$ \\
\hline $\mathrm{O}(1)-\mathrm{Mo}(1)-\mathrm{P}(1)$ & $98.36(5)$ & $\mathrm{P}(2)-\mathrm{Mo}(1)-\mathrm{P}(3)$ & $152.001(16)$ \\
$\mathrm{O}(1)-\mathrm{Mo}(1)-\mathrm{Cl}(2)$ & $98.70(5)$ & $\mathrm{O}(1)-\mathrm{Mo}(1)-\mathrm{Cl}(1)$ & $173.95(5)$ \\
$\mathrm{P}(1)-\mathrm{Mo}(1)-\mathrm{Cl}(2)$ & $162.923(16)$ & $\mathrm{P}(1)-\mathrm{Mo}(1)-\mathrm{Cl}(1)$ & $75.772(15)$ \\
$\mathrm{O}(1)-\mathrm{Mo}(1)-\mathrm{P}(2)$ & $101.58(5)$ & $\mathrm{Cl}(2)-\mathrm{Mo}(1)-\mathrm{Cl}(1)$ & $87.191(16)$ \\
$\mathrm{P}(1)-\mathrm{Mo}(1)-\mathrm{P}(2)$ & $80.353(15)$ & $\mathrm{P}(2)-\mathrm{Mo}(1)-\mathrm{Cl}(1)$ & $76.226(15)$ \\
$\mathrm{Cl}(2)-\mathrm{Mo}(1)-\mathrm{P}(2)$ & $96.915(16)$ & $\mathrm{P}(3)-\mathrm{Mo}(1)-\mathrm{Cl}(1)$ & $79.354(14)$ \\
$\mathrm{O}(1)-\mathrm{Mo}(1)-\mathrm{P}(3)$ & $101.31(5)$ &
\end{tabular}




\section{CV data}

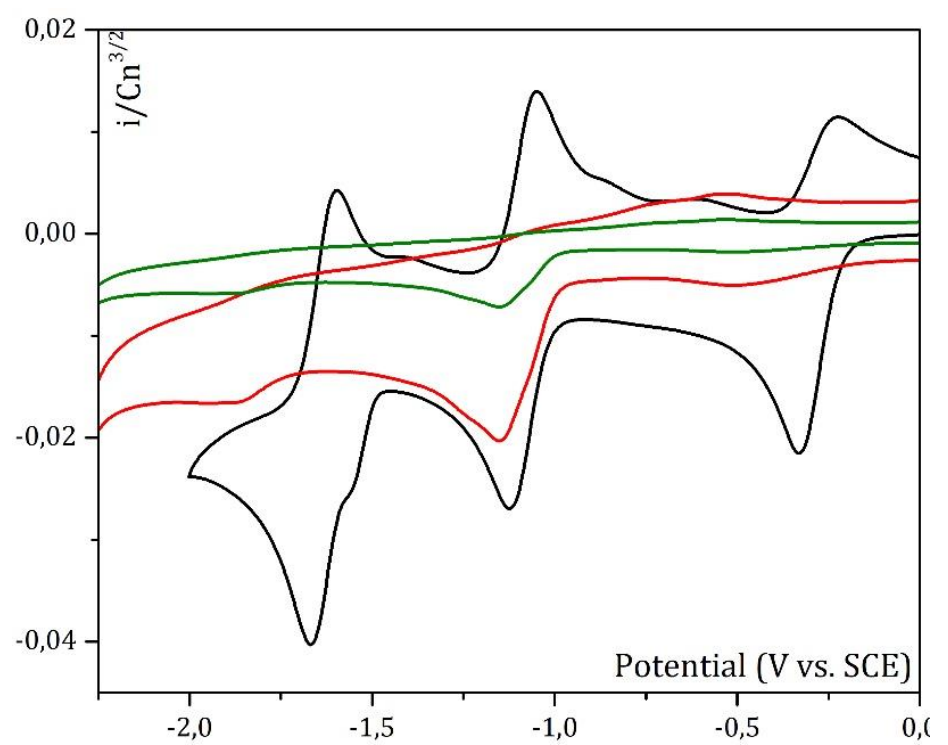

Figure S3. CVs at $3 \mathrm{~mm} \mathrm{GC}$ electrode in $\mathrm{THF}\left(0.1 \mathrm{M} \mathrm{Bu}_{4} \mathrm{~N}\left[\mathrm{Bar}^{\mathrm{F}}\right]\right)$ containing $1.2 \mathrm{mM} \mathrm{FeTPPCl}$ (black) or $0.58 \mathrm{mM} \mathrm{Mo} 2$ (red and green). At $v=100 \mathrm{mV} / \mathrm{s}$, under Ar. CVs are normalized for concentration $\mathrm{C}$ and number of exchanged electrons $\mathrm{n}$ (red trace: $\mathrm{n}=1$, green trace: $\mathrm{n}=2$ ).

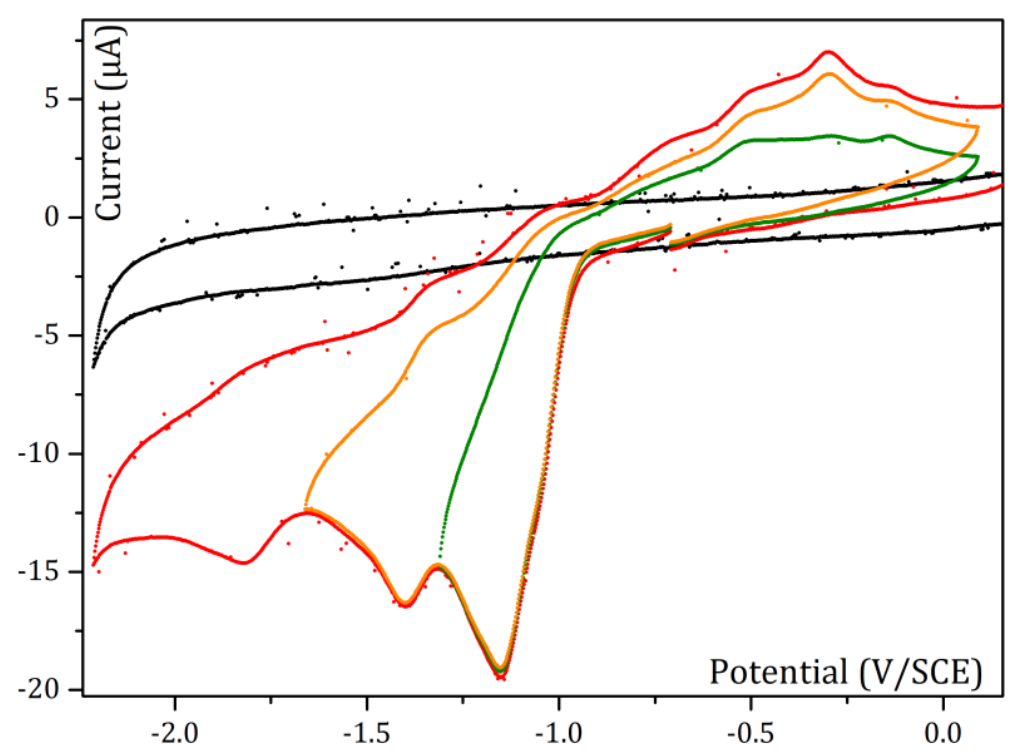

Figure S4. $\mathrm{CV}$ s at $3 \mathrm{~mm}$ GC electrode in $\mathrm{THF}(0.1 \mathrm{M} \mathrm{Bu} 4 \mathrm{~N}[\mathrm{Bar} F])$ containing $1 \mathrm{mM} \mathrm{Mo2} . v=100 \mathrm{mV} / \mathrm{s}$, under $\mathrm{N}_{2}$. 


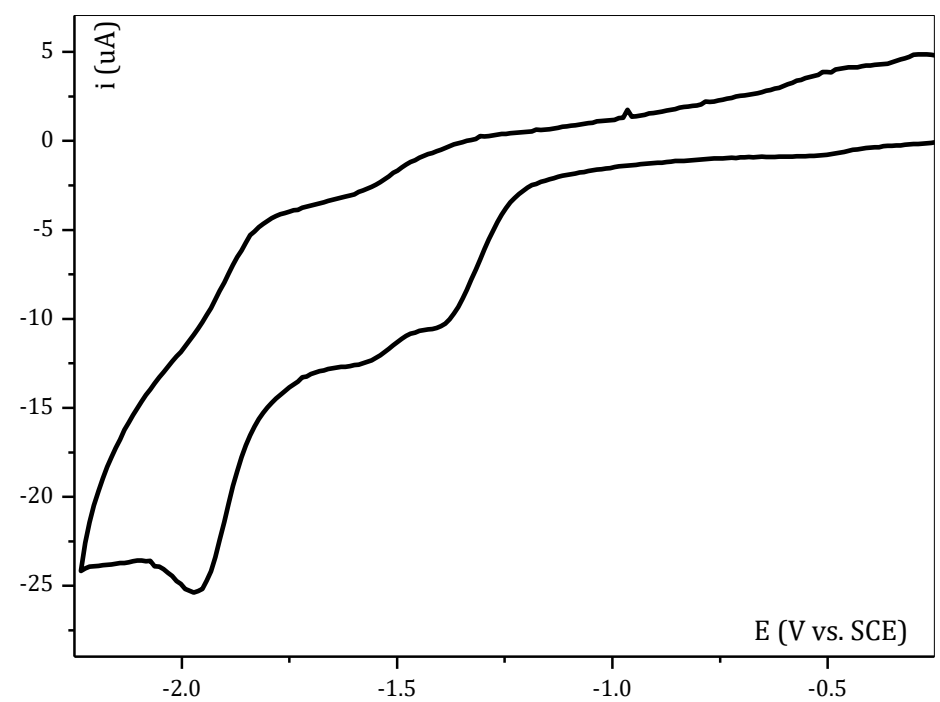

Figure S5. CVs at $3 \mathrm{~mm} \mathrm{GC}$ electrode in THF $\left(0.1 \mathrm{M} \mathrm{Bu} 4 \mathrm{~N}\left[\mathrm{Bar}^{\mathrm{F}}\right]\right)$ containing $1 \mathrm{mM}(\mathbf{P P P}) \mathbf{M o}=\mathbf{O}(\mathbf{C l}) 2 . v=100 \mathrm{mV} / \mathrm{s}$, under $\mathrm{N}_{2}$.

\section{Controlled Potential Electrolyses}

\section{CPE under $\mathrm{N}_{2}$}

A controlled potential electrolysis was performed in THF ( $\left.0.1 \mathrm{M} \mathrm{Bu}_{4} \mathrm{~N}\left[\mathrm{BAr}{ }_{4}{ }_{4}\right]\right)$ containing ca. $2.5 \mathrm{mM}$ Mo2, at $-1.4 \mathrm{~V} v s$. SCE, ie at the pc2 peak potential (see main text), in a $\mathrm{N}_{2}$ filled glovebox. A charge of $1.03 \mathrm{C}$ was passed, corresponding to $1.24 \mathrm{e}^{-}$per Mo atom. Before and after the electrolysis, CVs were recorded at a $1 \mathrm{~mm}$ glassy carbon electrode. After the CPE, the electrolyte solution was placed in Jyoung terminated NMR tube and concentrated, and NMR spectra were recorded.

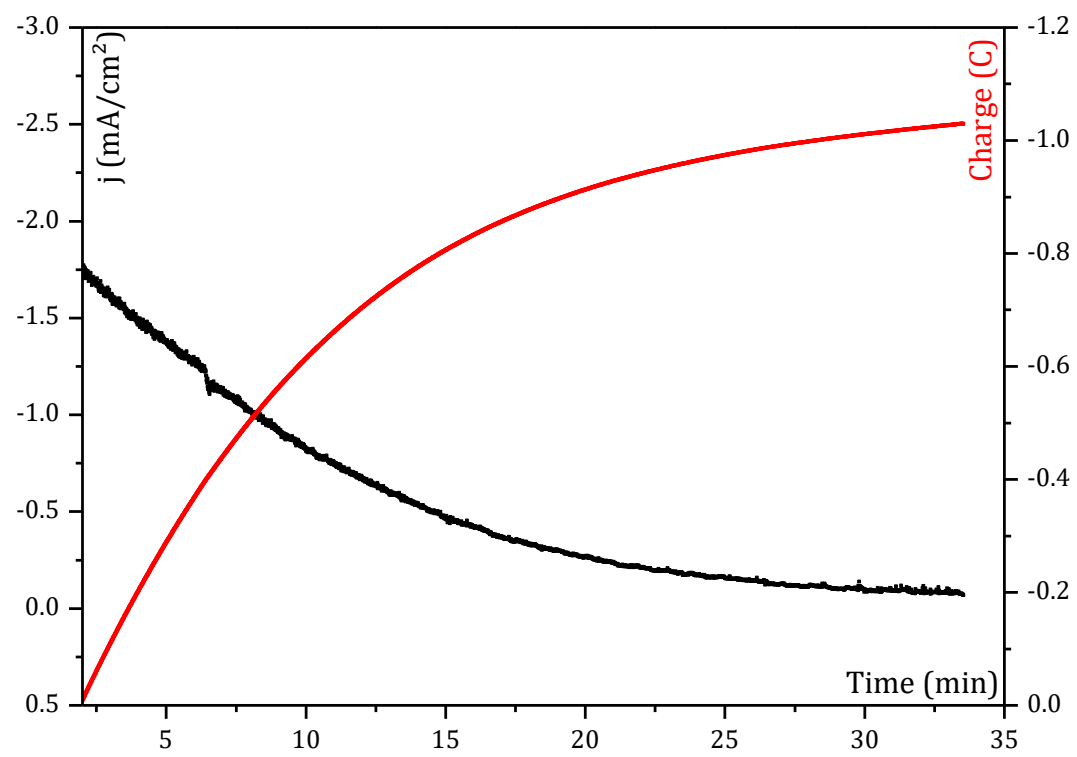

Figure S6. CA at $1 \mathrm{~cm}^{2} \mathrm{GC}$ electrode in $\operatorname{THF}\left(0.1 \mathrm{M} \mathrm{Bu}_{4} \mathrm{~N}\left[\mathrm{Bar}^{\mathrm{F}}\right]\right)$ containing $2.46 \mathrm{mM}$ Mo2, under $\mathrm{N}_{2}$. 


\section{CPE under Ar}

A solution of $2.5 \mathrm{mM} \mathrm{Mo2}$ in $\mathrm{THF}\left(0.1 \mathrm{M} \mathrm{Bu}_{4} \mathrm{~N}\left[\mathrm{BAr}_{4}{ }_{4}\right]\right)$ was prepared and placed in the electrochemical cell in the $\mathrm{N}_{2}$ filled glovebox, then degassed under an Ar stream for more than $30 \mathrm{~min}$. A CPE was performed at $-1.4 \mathrm{~V} v s$. SCE. After the electrolysis, $0.37 \mathrm{C}$ were exchanged, corresponding to $1 \mathrm{e}^{-} / \mathrm{Mo}$ center.

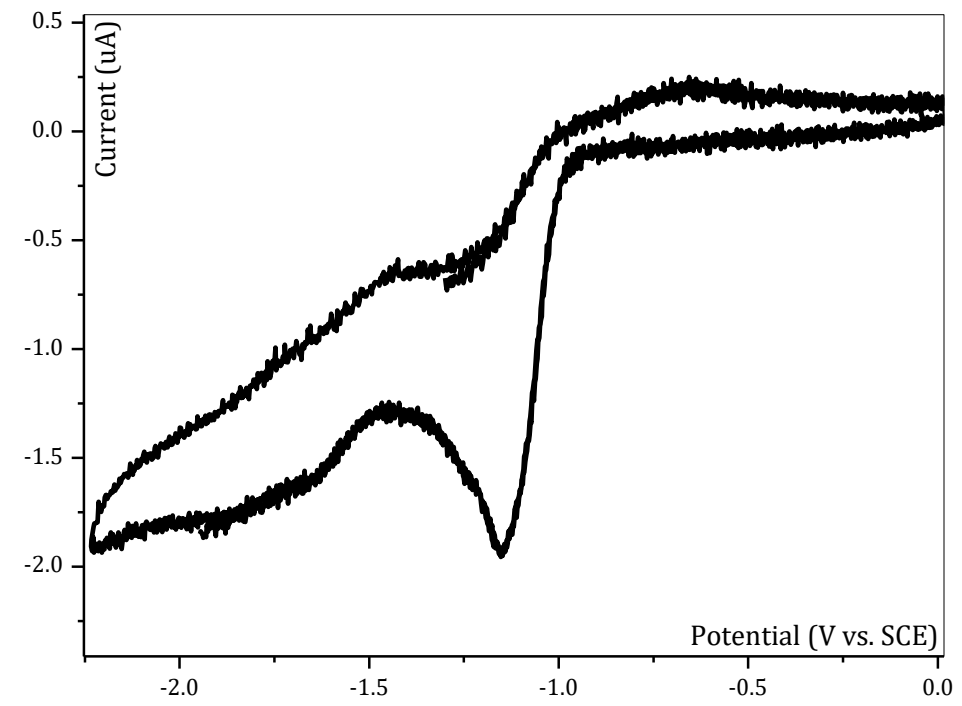

Figure S7. $\mathrm{CV}$ at $1 \mathrm{~mm}$ GC electrode in $\mathrm{THF}\left(0.1 \mathrm{M} \mathrm{Bu}_{4} \mathrm{~N}\left[\mathrm{BAr}{ }^{\mathrm{F}}\right]\right)$ containing $1 \mathrm{mM}$ Mo2 before electrolysis. At $v=100$ $\mathrm{mV} / \mathrm{s}$, under Ar.

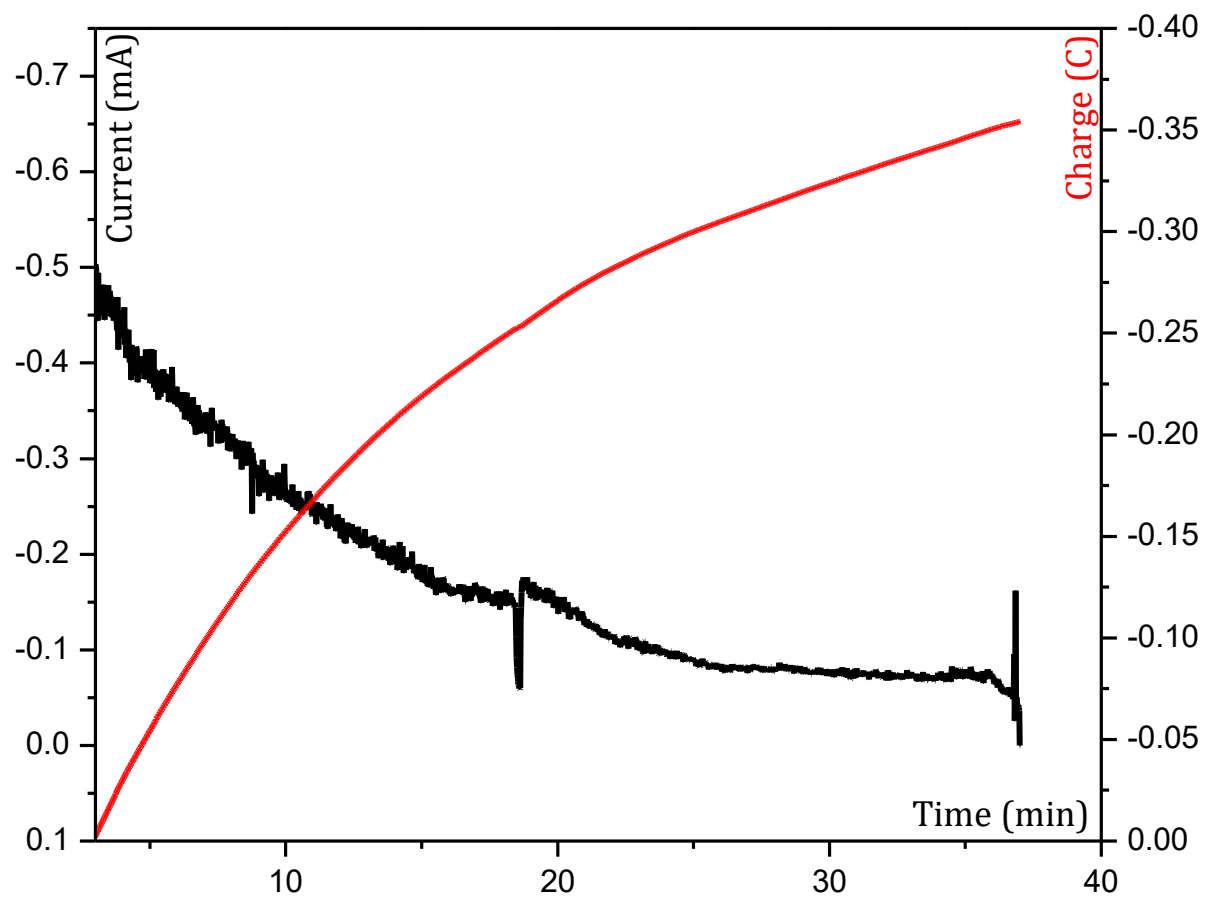

Figure S8. CA at $1 \mathrm{~cm}^{2} \mathrm{GC}$ electrode in $\operatorname{THF}\left(0.1 \mathrm{M} \mathrm{Bu}_{4} \mathrm{~N}\left[\mathrm{Bar}^{\mathrm{F}}\right]\right)$ containing $1 \mathrm{mM} \mathrm{Mo2}$, under Ar. 


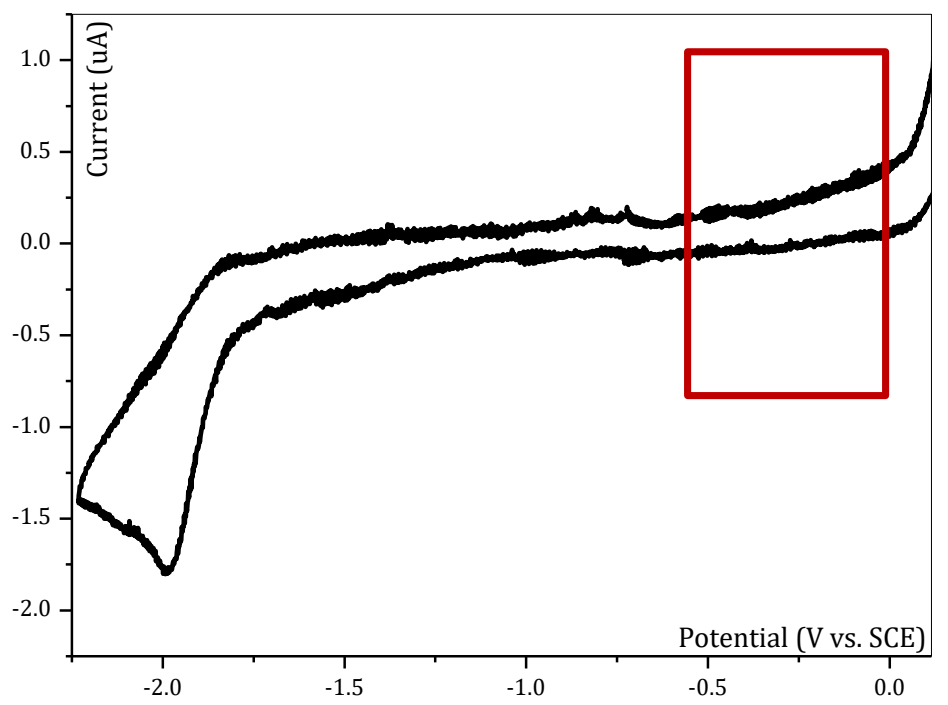

Figure S9. CV at $1 \mathrm{~mm} \mathrm{GC}$ electrode in the electrolyte solution after CPE of solution containing Mo2 under Ar. At $v=100$ $\mathrm{mV} / \mathrm{s}$, under Ar. The red square indicates the potential window in which the reversible oxidation of $\mathbf{M o}^{\mathbf{I V}} \mathbf{3}$ to $\mathbf{M o}^{\mathbf{v}} \mathbf{3}$ would be expected.

\section{NMR data}

\section{Supporting electrolytes}

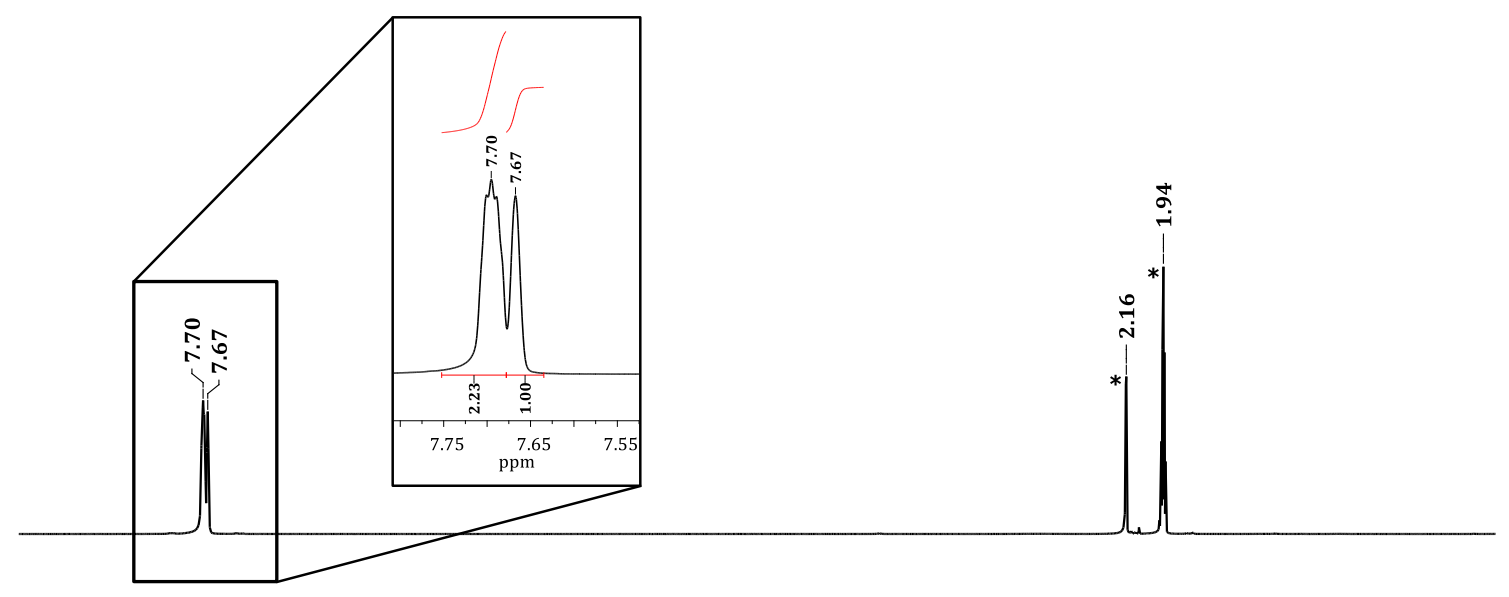

Figure S10. ${ }^{1} \mathrm{H}$ NMR spectrum of $\mathrm{Na}_{2}\left[\mathrm{Bar}^{\mathrm{F}} 4\right]$ in $\mathrm{CD}_{3} \mathrm{CN}$. * Solvent residual peaks $\left(\mathrm{H}_{2} \mathrm{O}\right.$ at $2.16 \mathrm{ppm}$ and $\mathrm{CH}_{3} \mathrm{CN}$ at 1.94 ppm). 


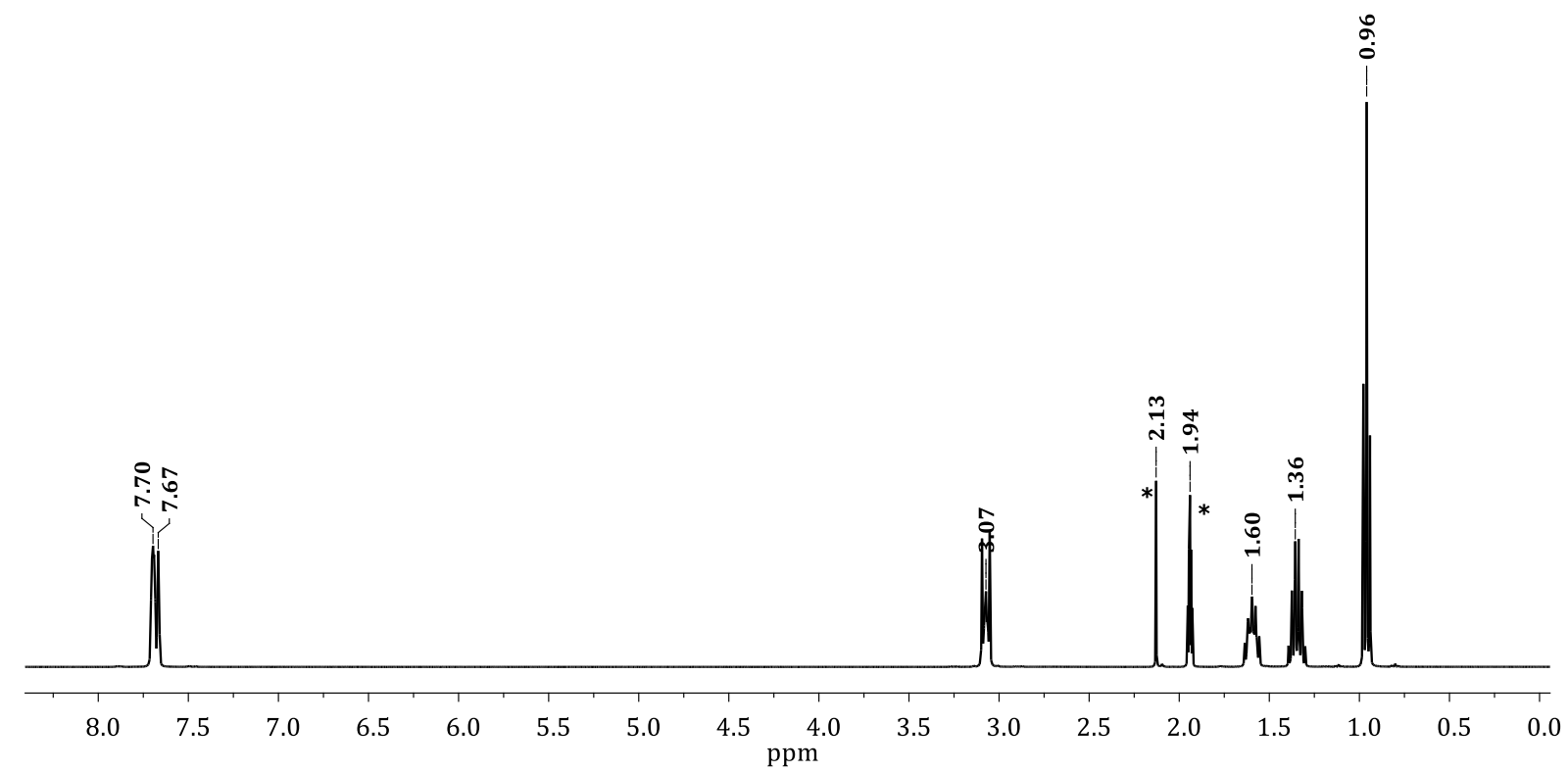

Figure S11. ${ }^{1} \mathrm{H}$ NMR spectrum of $\mathrm{Bu}_{4} \mathrm{~N}\left[\mathrm{Bar}_{4}\right]$ in $\mathrm{CD}_{3} \mathrm{CN}$. * Solvent residual peaks $\left(\mathrm{H}_{2} \mathrm{O}\right.$ at 2.16 ppm and $\mathrm{CH}_{3} \mathrm{CN}$ at 1.94 $\mathrm{ppm})$.

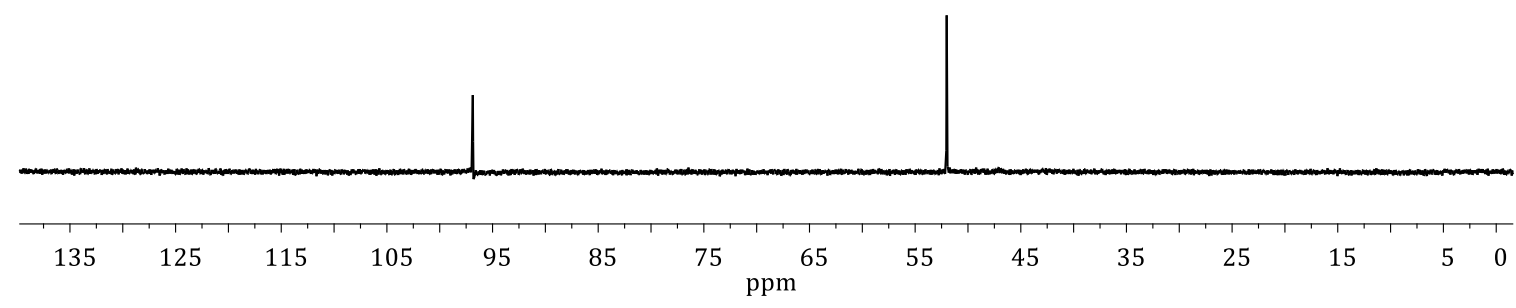

Figure S12. ${ }^{31} \mathrm{P}\left\{{ }^{1} \mathrm{H}\right\}$ NMR spectrum of an electrolyte solution after CPE under Ar. The experiment is described on page S9 (CPE under Ar).

\section{DFT}

Geometry optimizations were performed using Gaussian 16 (Revision A03) ${ }^{4}$ at the PBE0 level of hybrid density functional theory, ${ }^{5}$ with inclusion of $\mathrm{D} 3(\mathrm{bj})$ corrections in the optimization process. ${ }^{6,7}$ The geometries of all located extrema are given as xyz coordinates data in a separate file (Geom.xyz) in the SI. The atoms Co, C, H, N and P were represented by an svp basis set. ${ }^{8}$ The Mo and I atoms were represented by Dolg's pseudo potential and the associated basis set. ${ }^{9} 10$ The solvent (thf) influence was taken into consideration through single-point calculations on the gas-phase optimized geometries with SCRF calculations within the SMD model. ${ }^{11}$ For the SCRF calculations, the atoms were treated with a def2-qzvp basis set. ${ }^{12}$ All energies reported are Gibbs free energies obtained by summing the SMD energy (including D3 corrections) and the gas phase Gibbs contribution at $298 \mathrm{~K}$ and $1 \mathrm{~atm}$. 
Relative energies (as compared to ${ }^{\mathbf{5}} \mathbf{A}$ ) of all computed structures (Scheme 4, see main text) are given below. Exponent is the spin state.

$\begin{array}{cr}{ }^{5} \mathbf{A} & 0.00 \\ { }^{5} \mathbf{B} & -3.39 \\ { }^{3} \mathbf{C} & -2.75 \\ { }^{5} \mathbf{C} & -3.97 \\ \mathbf{T S}\left({ }^{3} \mathbf{C}-{ }^{3} \mathbf{D}\right) & 13.07 \\ { }^{\mathbf{3}} \mathbf{D} & -1.23 \\ { }^{\mathbf{1}} \mathbf{C}-\mathbf{D} & 5.58 \\ { }^{3} \mathbf{C}-\mathbf{D} & 0.93 \\ \mathbf{T S}\left({ }^{1} \mathbf{C}-\mathbf{D}-\mathbf{N}_{2}\right) & 57.61 \\ \mathbf{T S}\left({ }^{3} \mathbf{C}-\mathbf{D}-\mathbf{N}_{2}\right) & 38.24 \\ { }^{2} \mathbf{E} & 1.52 \\ \mathbf{T S}\left({ }^{2} \mathbf{E}-{ }^{2} \mathbf{F}\right) & 9.89 \\ { }^{2} \mathbf{F} & -1.56 \\ { }^{1} \mathbf{E}-\mathbf{F} & -15.26 \\ { }^{3} \mathbf{E}-\mathbf{F} & -15.44 \\ \mathbf{T S}\left({ }^{1} \mathbf{E}-\mathbf{F}-{ }^{\mathbf{1}} \mathbf{G}\right) & 5.78 \\ \mathbf{T S}\left({ }^{3} \mathbf{E}-\mathbf{F}-{ }^{1} \mathbf{G}\right) & 49.54 \\ { }^{1} \mathbf{G} & -55.31\end{array}$

\section{Abreviations}

$\mathrm{BAr}_{4}{ }_{4}$ 3,5-bis(trifluoromethyl)phenylborate

$\mathrm{Bu}_{4} \mathrm{~N}$ Tetrabutylammonium

CPE Controlled Potential Electrolysis

$\mathrm{Cp}_{2}{ }^{*}$ CoDecamethylcobaltocene

DFT Density Functional Theory

E Potential

$\mathrm{Fc} / \mathrm{Fc}^{+}$Ferrocene/Ferrocenium reference redox couple

$\mathrm{H}$ - B Haber - Bosch process

NMR Nuclear Magnetic Resonance

PCET Proton Coupled Electron Transfer

RT Room Temperature

SCE Saturated Calomel Electrode

THF Tetrahydrofuran

\section{References}

(1) Liao, Q.; Cavaillé, A.; Saffon-Merceron, N.; Mézailles, N. Direct Synthesis of Silylamine from N2and a Silane: Mediated by a Tridentate Phosphine Molybdenum Fragment. Angew. Chemie Int. Ed. 2016, 55 (37), 11212-11216. https://doi.org/10.1002/anie.201604812.

(2) Cotton, F. A.; Poli, R. Low-Valent Molybdenum Carbonyl Complexes as an Entry to Octahedral MoI3L3 Complexes. Synthesis and X-Ray Molecular Structure of MoI3(THF)3. Inorg. Chem. 1987, 26 (10), 1514-1518. https://doi.org/10.1021/ic00257a011.

(3) Martínez-Martínez, A. J.; Weller, A. S. Solvent-Free Anhydrous Li+, Na+ and K+ Salts of [B(3,5-(CF3)2C6H3)4]-, [BArF4]-. Improved Synthesis and Solid-State Structures. Dalt. Trans. 2019, 48 (11), 3551-3554. https://doi.org/10.1039/c9dt00235a. 
(4) Frisch, M. J.; Trucks, G. W.; Schlegel, H. B.; Scuseria, G. E.; Robb, M. A.; Cheeseman, J. R.; Scalmani, G.; Barone, V.; Petersson, G. A.; Nakatsuji, H.; Li, X.; Caricato, M.; Marenich, A. V.; Bloino, J.; Janesko, B. G.; Gomperts, R.; Mennucci, B.; Hratchian, H. P.; Ortiz, J. V.; Izmaylov, A. F.; Sonnenberg, J. L.; Williams-Young, D.; Ding, F.; Lipparini, F.; Egidi, F.; Goings, J.; Peng, B.; Petrone, A.; Henderson, T.; Ranasinghe, D.; Zakrzewski, V. G.; Gao, J.; Rega, N.; Zheng, G.; Liang, W.; Hada, M.; Ehara, M.; Toyota, K.; Fukuda, R.; Hasegawa, J.; Ishida, M.; Nakajima, T.; Honda, Y.; Kitao, O.; Nakai, H.; Vreven, T.; Throssell, K.;

Montgomery, J. A., J.; Peralta, J. E.; Ogliaro, F.; Bearpark, M. J.; Heyd, J. J.; Brothers, E. N.; Kudin, K. N.; Staroverov, V. N.; Keith, T. A.; Kobayashi, R.; Normand, J.; Raghavachari, K.; Rendell, A. P.; Burant, J. C.; Iyengar, S. S.; Tomasi, J.; Cossi, M.; Millam, J. M.; Klene, M.; Adamo, C.; Cammi, R.; Ochterski, J. W.; Martin, R. L.; Morokuma, K.; Farkas, O.; Foresman, J. B.; Fox, D. J. Gaussian 16, Revision A.03. Gaussian Inc.: Wallingford CT 2016.

(5) Adamo, C.; Barone, V. Toward Reliable Density Functional Methods without Adjustable Parameters: The PBE0 Model. J. Chem. Phys. 1999, 110 (13), 6158-6170. https://doi.org/10.1063/1.478522.

(6) Grimme, S.; Antony, J.; Ehrlich, S.; Krieg, H. A Consistent and Accurate Ab Initio Parametrization of Density Functional Dispersion Correction (DFT-D) for the 94 Elements HPu. J. Chem. Phys. 2010, 132 (15). https://doi.org/10.1063/1.3382344.

(7) Grimme, S.; Ehrlich, S.; Goerigk, L. Effect of the Damping Function in Dispersion Corrected Density Functional Theory. J. Comput. Chem. 2011, 32, 1456-1465.

(8) Schäfer, A.; Horn, H.; Ahlrichs, R. Fully Optimized Contracted Gaussian Basis Sets for Atoms Li to Kr. J. Chem. Phys. 1992, 97 (4), 2571-2577. https://doi.org/10.1063/1.463096.

(9) Andrae, D.; Häußermann, U.; Dolg, M.; Stoll, H.; Preuß, H. Energy-Adjusted Ab Initio Pseudopotentials for the Second and Third Row Transition Elements. Theor. Chim. Acta 1990, 77 (2), 123-141. https://doi.org/10.1007/BF01114537.

(10) Peterson, K. A.; Figgen, D.; Goll, E.; Stoll, H.; Dolg, M. Systematically Convergent Basis Sets with Relativistic Pseudopotentials. II. Small-Core Pseudopotentials and Correlation Consistent Basis Sets for the Post-d Group 16-18 Elements. J. Chem. Phys. 2003, 119 (21), 11113-11123. https://doi.org/10.1063/1.1622924.

(11) Marenich, A. V.; Cramer, C. J.; Truhlar, D. G. Universal Solvation Model Based on Solute Electron Density and on a Continuum Model of the Solvent Defined by the Bulk Dielectric Constant and Atomic Surface Tensions. J. Phys. Chem. B 2009, 113 (18), 6378-6396. https://doi.org/10.1021/jp810292n.

(12) Weigend, F.; Ahlrichs, R. Balanced Basis Sets of Split Valence, Triple Zeta Valence and Quadruple Zeta Valence Quality for H to Rn: Design and Assessment of Accuracy. Phys. Chem. Chem. Phys. 2005, 7 (18), 3297-3305. https://doi.org/10.1039/b508541a. 